Supporting Information (SI) for

\title{
A Tetraindeno-Fused Bis(anthraoxa)quinodimethane with Nine Consecutively Fused Six-Membered Rings
}

Johnathan Joo Cheng Lee, Shaoqiang Dong,* Albert Ong, Yi Han, Jishan Wu, Chunyan Chi*

Department of Chemistry, National University of Singapore, 3 Science Drive 3, 117543, Singapore

\section{Contents}

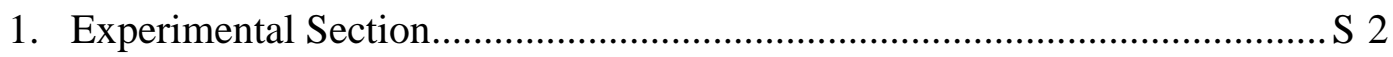

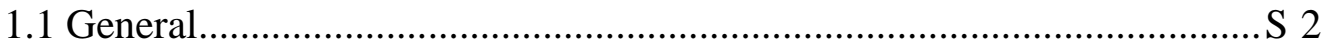

1.2 Synthetic procedures and characterization data.....................................S2

1.3 Chemical oxidation and reduction of RBR...........................................S6

1.4 Method for the crystal growth of RBR ...............................................S7

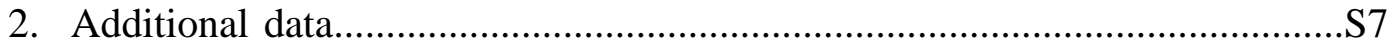

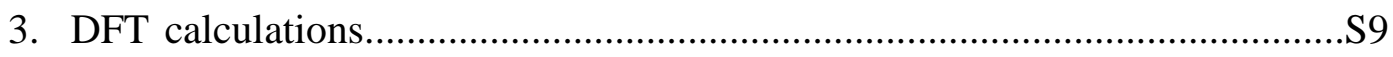

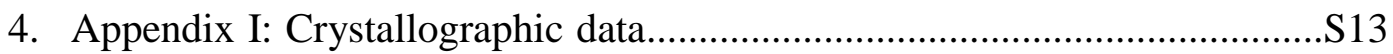

5. Appendix II: ${ }^{1} \mathrm{H}$ NMR and ${ }^{13} \mathrm{C}$ NMR spectra of all new compounds............S16

6. Appendix III: High resolution mass spectrum of RBR .............................S21 


\section{Experimental Section}

\subsection{General}

All reagents were purchased from commercial sources without further purification. Anhydrous dichloromethane (DCM) was distilled from $\mathrm{CaH}_{2}$. Anhydrous toluene and THF were distilled from sodium-benzophenone immediately prior to use. Nitromethane $\left(\mathrm{MeNO}_{2}\right)$ was purchased from commercial source and was dried over $\mathrm{Na}_{2} \mathrm{SO}_{4}$ before using. The other solvents used in the synthesis were AR grade without further purification. ${ }^{1} \mathrm{H}$ and ${ }^{13} \mathrm{C} \mathrm{NMR}$ spectra were recorded using Advance $500 \mathrm{MHz}$ Bruker spectrometer in $\mathrm{CDCl}_{3}, \mathrm{CD}_{2} \mathrm{Cl}_{2}$ or $\mathrm{C}_{6} \mathrm{D}_{6}$ with tetramethylsilane (TMS) as the internal standard. The chemical shift was recorded in ppm and the following abbreviations were used to explain the multiplicities: $\mathrm{s}=$ singlet, $\mathrm{d}=$ doublet, $\mathrm{t}=$ triplet, $\mathrm{m}=$ multiplet, $\mathrm{br}$ = broad. High-resolution (HR) APCI mass spectra were recorded on a MicrOTOF-QII instrument. UV-vis absorption spectra were recorded on a Shimadzu UV-3600 spectrophotometer. Cyclic voltammetry and differential pulse voltammetry measurements were performed in dry dichloromethane on a CHI $620 \mathrm{C}$ electrochemical analyzer with a three-electrode cell, using $0.1 \mathrm{M} \mathrm{Bu}_{4} \mathrm{NPF}_{6}$ as supporting electrolyte, $\mathrm{AgCl} / \mathrm{Ag}$ as reference electrode, gold disk as working electrode, $\mathrm{Pt}$ wire as counter electrode, and scan rate at $50 \mathrm{mV} \mathrm{s}^{-1}$ for $\mathrm{CV}$. The potential was externally calibrated against the ferrocene/ferrocenium couple. Single crystals were measured at low temperature ( $\mathrm{T}=100 \mathrm{~K}$ ) on a four circles goniometer Kappa geometry Bruker AXS D8 Venture equipped with a Photon 100 CMOS active pixel sensor detector using a Molybdenum monochromatized $(\lambda=0.71073 \AA)$ X-ray radiation or using a Copper monochromatized $(\lambda=1.54178 \AA) \mathrm{X}$-ray radiation.

\subsection{Synthetic procedures and characterization data}

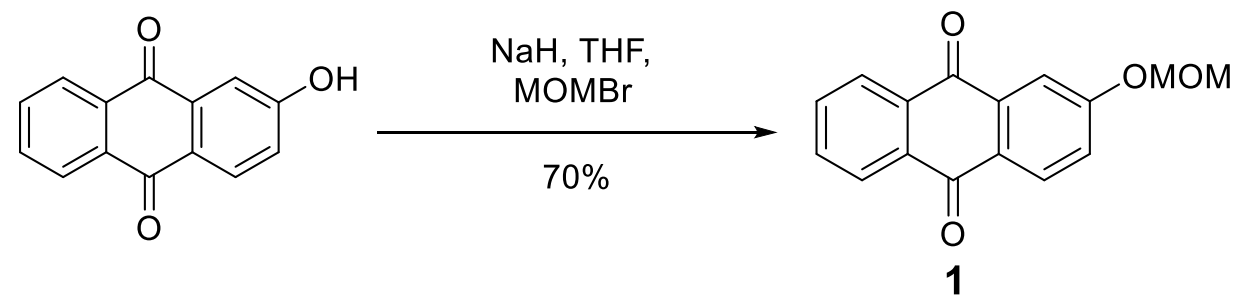

2-Hydroxylanthraquinone (4.48 g, $20.0 \mathrm{mmol})$ and $\mathrm{NaH}(0.50 \mathrm{~g}, 20.1 \mathrm{mmol})$ were added in a $250 \mathrm{~mL}$ round bottom flask (RBF) containing $100 \mathrm{~mL}$ of anhydrous THF. Methoxybromomethyl ether $(2.82 \mathrm{ml}, 30.0 \mathrm{mmol})$ was added dropwise to the reaction mixture upon stirring. The reaction was stirred under $\mathrm{N}_{2}$ atmosphere and produced a reddish solution upon stirring. The reaction was left to run for $24 \mathrm{hrs}$. The reaction progress was monitored using TLC analysis. Thereafter, the crude product was extracted using DCM (3 $\times 20 \mathrm{~mL})$, the combined organic layer was then washed with $\mathrm{NaCl}$ brine and dried over anhydrous $\mathrm{Na}_{2} \mathrm{SO}_{4}$. The solvent was then removed, and 
further purification was conducted using column chromatography with DCM/hexacene as eluent $\left(R_{\mathrm{f}}=0.75,2 / 1, \mathrm{v} / \mathrm{v}\right)$ to produce a yellow solid $\mathbf{1}(3.75 \mathrm{~g})$ in $70 \%$ yield. ${ }^{1} \mathrm{H}$ NMR (500 MHz, $\left.\mathrm{CDCl}_{3}\right): \delta(\mathrm{ppm}) 8.31-8.26(\mathrm{~m}, 3 \mathrm{H}), 7.87(\mathrm{~d}, J=2.6 \mathrm{~Hz}, 1 \mathrm{H}), 7.79-$ 7.77 (m, 2H), 7.39 (dd, $J=8.8 \mathrm{~Hz}, 2.6 \mathrm{~Hz}, 1 \mathrm{H}), 5.34$ (d, $J=3.4 \mathrm{~Hz}, 2 \mathrm{H}), 3.52$ (s, 3H). ${ }^{13} \mathrm{C} \mathrm{NMR}\left(125 \mathrm{MHz}, \mathrm{CDCl}_{3}\right): \delta(\mathrm{ppm}) 182.9,182.1,161.9,135.5,134.1,133.7,133.6$, 129.7, 127.8, 127.1, 122.0, 113.1, 94.2, 56.5. HRMS (APCI) $\mathrm{m} / \mathrm{z}:[\mathrm{M}+\mathrm{H}]^{+}$calcd for $\mathrm{C}_{16} \mathrm{H}_{13} \mathrm{O}_{4}$ : 269.0806; found 269.0808 (error $1.0 \mathrm{ppm}$ ).

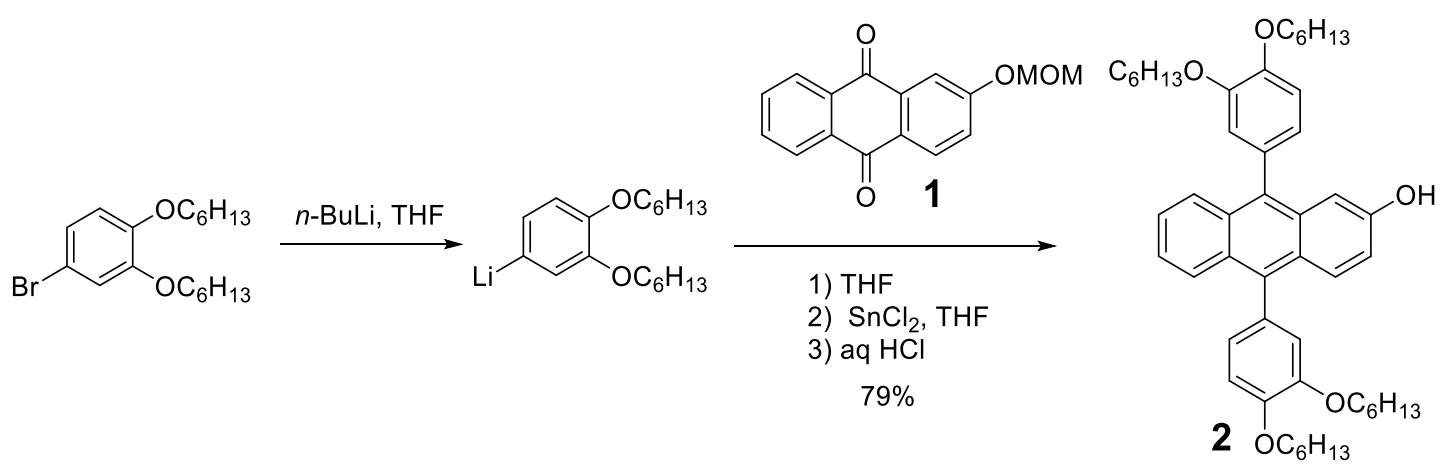

In nitrogen atmosphere, 4-bromo-1,2-bis(hexyloxy)benzene $(2.75 \mathrm{~g}, 7.71 \mathrm{mmol})$ was dissolved in $80 \mathrm{~mL}$ of THF at $-78{ }^{\circ} \mathrm{C}$ in a dry ice bath, $n$-butyllithium $(3.8 \mathrm{ml}, 7.70$ mmol) was added into the reaction mixture. One hour later, $1(0.69 \mathrm{~g}, 2.50 \mathrm{mmol})$ was added as a solid at $-78{ }^{\circ} \mathrm{C}$ using a dry ice bath, the mixture was allowed to gradually warm to room temperature in $12 \mathrm{hrs}$. Thereafter, $\mathrm{SnCl}_{2}(1.89 \mathrm{~g}, 10 \mathrm{mmol})$ was added to the orange reaction mixture before concentrated $\mathrm{HCl}(2 \mathrm{~mL}, 20 \mathrm{mmol})$ was added. The reaction mixture was then allowed to stir for another $12 \mathrm{hrs}$. The crude products in the resulting reaction mixture, a bright orange solution which produced a blue fluorescent glow, was extracted with diethyl either $(3 \times 30 \mathrm{~mL})$ and the combined organic layer was then washed with $\mathrm{NaCl}(3 \times 30 \mathrm{ml})$ brine and dried over anhydrous $\mathrm{Na}_{2} \mathrm{SO}_{4}$. The solvent was then removed and the crude product was purified by column chromatography with DCM/hexacene as eluent $\left(R_{\mathrm{f}}=0.75,3 / 1, \mathrm{v} / \mathrm{v}\right)$ to afford a bright orange yellow solid 2 $(2.55 \mathrm{~g})$ in $79 \%$ yield. ${ }^{1} \mathrm{H}$ NMR $\left(500 \mathrm{MHz}, \mathrm{CDCl}_{3}\right): \delta(\mathrm{ppm}) 7.74(\mathrm{t}, J=10.0 \mathrm{~Hz}, 2 \mathrm{H})$, $7.69(\mathrm{~d}, J=10.0 \mathrm{~Hz}, 1 \mathrm{H}), 7.33-7.27(\mathrm{~m}, 2 \mathrm{H}), 7.11(\mathrm{dd}, J=5.0 \mathrm{~Hz}, 10.0 \mathrm{~Hz}, 1 \mathrm{H}), 7.07-$ $7.05(\mathrm{~m}, 3 \mathrm{H}), 7.03-6.95(\mathrm{~m}, 4 \mathrm{H}), 4.18-4.10(\mathrm{~m}, 4 \mathrm{H}), 4.00-3.95(\mathrm{~m}, 4 \mathrm{H}), 1.95-1.92(\mathrm{~m}$, 2H), $1.86-1.78(\mathrm{~m}, 6 \mathrm{H}), 1.58(\mathrm{br}, 1 \mathrm{H}), 1.48-1.23(\mathrm{~m}, 24 \mathrm{H}), 0.97-0.82(\mathrm{~m}, 12 \mathrm{H}) .{ }^{13} \mathrm{C}$ NMR (125 MHz, $\left.\mathrm{CDCl}_{3}\right): \delta(\mathrm{ppm}) 153.1,148.9,148.7,148.5,148.0,137.2,134.3$, $131.8,131.6,131.5,130.6,129.4,128.7,127.2,126.6,126.5,125.1,123.9,123.7,123.4$, 119.0, 116.9, 116.3, 113.6, 113.1, 106.8, 69.5, 69.3, 69.2, 31.7, 31.65, 31.62, 31.57, 29.4, 29.3, 29.1, 25.85, 25.81, 25.7, 22.7, 22.62, 22.60, 22.56, 14.08, 14.05, 14.01, 13.97. HRMS (APCI) m/z: $[\mathrm{M}+\mathrm{H}]^{+}$calcd for $\mathrm{C}_{50} \mathrm{H}_{67} \mathrm{O}_{5}$ 747.4983; Found 747.4979 (error $0.6 \mathrm{ppm}$ ). 

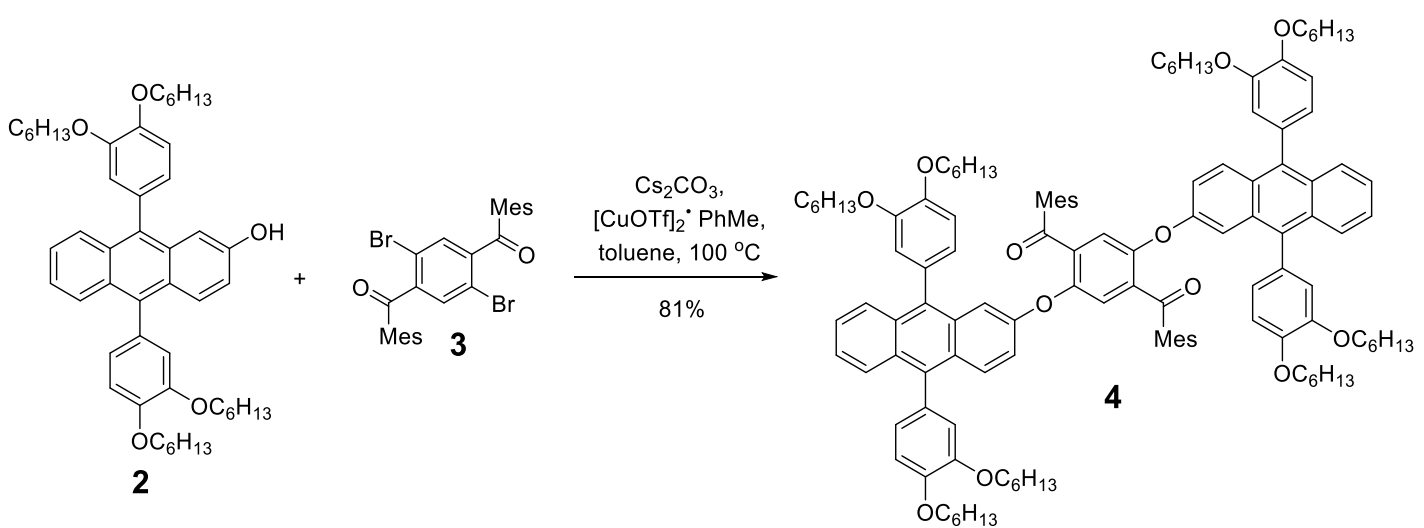

Compouds 2 ( $0.40 \mathrm{~g}, 0.57 \mathrm{mmol}), 3$ (0.10 g, $0.18 \mathrm{mmol}), \mathrm{Cs}_{2} \mathrm{CO}_{3}(0.30 \mathrm{~g}, 0.92 \mathrm{mmol})$ and $[\mathrm{CuOTf}]_{2} \cdot \mathrm{PhMe}(0.01 \mathrm{~g}, 0.1 \mathrm{~mol} \%)$ was added into a $100 \mathrm{~mL}$ schlenk tube, then $10 \mathrm{~mL}$ of anhydrous toluene was added. The reaction mixture was then subjected to three degassed cycles of freeze-thaw pump technique. The mixture was then warmed to $100{ }^{\circ} \mathrm{C}$ using an oil bath, and stirred for 5 days. The orange yellow suspension turned into a dark brown solution after the completion of the reaction. The crude product was extracted with toluene $(3 \times 30 \mathrm{~mL})$ and the combined organic layer was then washed with $\mathrm{NaCl}(2 \times 30 \mathrm{~mL})$ brine and dried over anhydrous $\mathrm{Na}_{2} \mathrm{SO}_{4}$. The solvent was then removed and the crude product was purified by column chromatography with $\mathrm{DCM} /$ hexacene as eluent $\left(R_{\mathrm{f}}=0.75,3 / 1, \mathrm{v} / \mathrm{v}\right)$ to afford a yellow solid $4(2.55 \mathrm{~g})$ in $81 \%$ yield. ${ }^{1} \mathrm{H}$ NMR $\left(500 \mathrm{MHz}, \mathrm{CDCl}_{3}\right): \delta(\mathrm{ppm}) 7.76\left(\mathrm{dd}, J^{3}=7.1 \mathrm{~Hz}, J^{4}=2.5 \mathrm{~Hz}, 2 \mathrm{H}\right)$, $7.72(\mathrm{~d}, J=8.3 \mathrm{~Hz}, 2 \mathrm{H}), 7.67(\mathrm{~d}, J=9.7 \mathrm{~Hz}, 2 \mathrm{H}), 7.38-7.36(\mathrm{~m}, 2 \mathrm{H}), 7.36-7.29(\mathrm{~m}, 4 \mathrm{H})$, $7.13(\mathrm{~d}, J=8.0 \mathrm{~Hz}, 2 \mathrm{H}), 7.06-7.04(\mathrm{~m}, 2 \mathrm{H}), 7.00-6.97(\mathrm{~m}, 6 \mathrm{H}), 6.96-6.90(\mathrm{~m}, 4 \mathrm{H}), 6.69$ $\left(\mathrm{dd}, J^{3}=9.4 \mathrm{~Hz}, J^{4}=2.9 \mathrm{~Hz}, 2 \mathrm{H}\right), 6.58(\mathrm{~s}, 4 \mathrm{H}), 4.20-4.17(\mathrm{t}, J=6.6 \mathrm{~Hz}, 4 \mathrm{H}), 4.14-4.10$ (m, 4H), 4.04-4.00 (m, 4H), $3.97(\mathrm{q}, J=6.5 \mathrm{~Hz}, 4 \mathrm{H}), 2.05(\mathrm{~s}, 6 \mathrm{H}), 1.98-1.90(\mathrm{~m}, 20 \mathrm{H})$, $1.88-1.79(\mathrm{~m}, 8 \mathrm{H}), 1.62-1.55$ (m, 8H), 1.50-1.39 (m, 24H), 1.36-1.30 (m, 16H), 1.00$0.87(\mathrm{~m}, 24 \mathrm{H}) .{ }^{13} \mathrm{C}$ NMR $\left(125 \mathrm{MHz}, \mathrm{CDCl}_{3}\right): \delta$ (ppm) 197.5, 153.6, 150.86.1, 149.0, 148.6, 137.8, 137.1, 135.7, 134.1, 131.3, 130.6, 130.4, 129.4, 129.3, 128.3, 127.3, 127.1, $126.7,125.2,124.4,123.5,122.8,118.6,116.8,113.7,69.3,31.6,29.3,25.7,22.5,20.8$, 19.6, 13.9. HRMS (APCI) $\mathrm{m} / \mathrm{z}$ : $[\mathrm{M}+\mathrm{H}]^{+}$calcd for $\mathrm{C}_{126} \mathrm{H}_{155} \mathrm{O}_{12}$ 1860.1519; Found 1860.1525 (error $0.3 \mathrm{ppm})$.
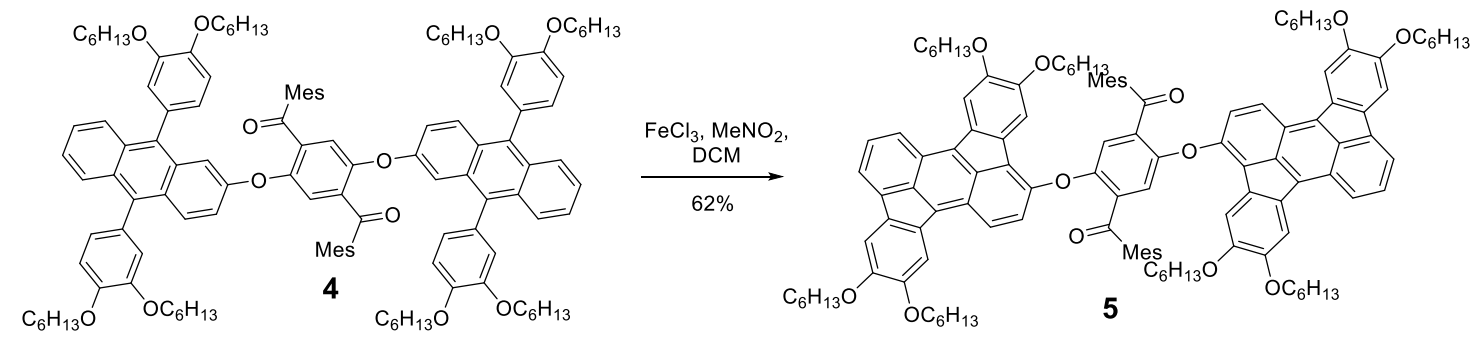

Compound 4 (0.22 g, $0.12 \mathrm{mmol})$ was added into a dried $500 \mathrm{~mL}$ two-neck RBF, 200 $\mathrm{mL}$ of anhydrous DCM was added to dissolve it. The solution was bubbled with a constant $\mathrm{N}_{2}$ gas throughout this reaction. A solution of anhydrous $\mathrm{FeCl}_{3}(0.30 \mathrm{~g}, 1.91$ mmol) in $2.0 \mathrm{~mL}$ of $\mathrm{MeNO}_{2}$ was added dropwise into the reaction mixture and allowed to stir for further 30 minutes. Thereafter, the reaction mixture was quenched with 20 
$\mathrm{mL}$ of methanol and washed with $\mathrm{NaCl}$ brine $(3 \times 30 \mathrm{~mL})$. the organic layer was then collected and dried over anhydrous $\mathrm{Na}_{2} \mathrm{SO}_{4}$. The solvent was then removed, the crude product of 5 was purified by column chromatography with DCM/hexacene as eluent $\left(R_{\mathrm{f}}=0.75,3 / 1, \mathrm{v} / \mathrm{v}\right)$ to afford a purple solid upon removal of solvent with a moderate yield $(0.137 \mathrm{~g})$ of $62 \% .{ }^{1} \mathrm{H} \mathrm{NMR}\left(500 \mathrm{MHz}, \mathrm{CDCl}_{3}\right): \delta(\mathrm{ppm}) 8.44(\mathrm{~d}, J=8.5 \mathrm{~Hz}, 2 \mathrm{H})$, $8.36(\mathrm{~s}, 2 \mathrm{H}), 7.86(\mathrm{~s}, 4 \mathrm{H}), 7.78-7.72(\mathrm{~m}, 4 \mathrm{H}), 7.65(\mathrm{~s}, 2 \mathrm{H}), 7.50(\mathrm{~d}, J=11.0 \mathrm{~Hz}, 4 \mathrm{H}), 7.09$ $(\mathrm{s}, 2 \mathrm{H}), 6.47(\mathrm{~s}, 4 \mathrm{H}), 4.25-4.14(\mathrm{~m}, 16 \mathrm{H}), 2.10(\mathrm{~s}, 12 \mathrm{H}), 1.96-1.90(\mathrm{~m}, 16 \mathrm{H}), 1.79(\mathrm{~s}, 6 \mathrm{H})$, 1.61-1.55 (m, 16H), 1.45-1.39 (m, 32H), 0.97-0.92 (m, 24H). The ${ }^{13} \mathrm{C}$ NMR spectrum of of 5 can not be recorded due to the aggregation of the compound in common deuterated solvents. HRMS (APCI) m/z: $[\mathrm{M}+\mathrm{H}]^{+}$calcd for $\mathrm{C}_{126} \mathrm{H}_{147} \mathrm{O}_{12}$ 1852.0893; Found 1852.0893 (error $0.0 \mathrm{ppm}$ ).

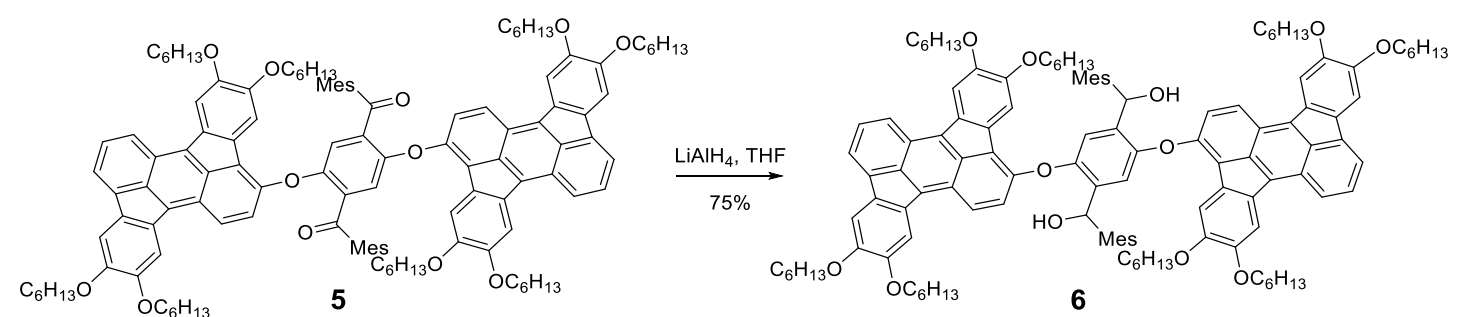

Compound 5 ( $0.12 \mathrm{~g}, 0.07 \mathrm{mmol})$ was dissolved in $100 \mathrm{~mL}$ of anhydrous THF in $\mathrm{N}_{2}$ atmosphere. $\mathrm{LiAlH}_{4}(0.05 \mathrm{~g}, 1.34 \mathrm{mmol})$ was then added to the reaction mixture upon stirring. The reaction produced a reddish solution upon stirring and the reaction was left to run for $2 \mathrm{hrs}$. Thereafter, the crude product was extracted using diethyl ether ( 3 x 20 $\mathrm{mL}$ ), the combined organic layer was then washed with $\mathrm{NaCl}$ brine and dried over anhydrous $\mathrm{Na}_{2} \mathrm{SO}_{4}$. The solvent was then removed, and further purification was conducted by column chromatography on silica gel with hexane/DCM (4/1, v/v) as eluent to give a reddish brown solid $6(0.097 \mathrm{~g})$ in $75 \%$ yield. Clear NMR spectrums of 6 could not be obtained due to its low solubility and strong aggregation in common deuterated solvents. HRMS (APCI) m/z: [M] calcd for $\mathrm{C}_{126} \mathrm{H}_{150} \mathrm{O}_{10}$ 1855.1127; Found 1855.1122 (error $-0.3 \mathrm{ppm}$ ).

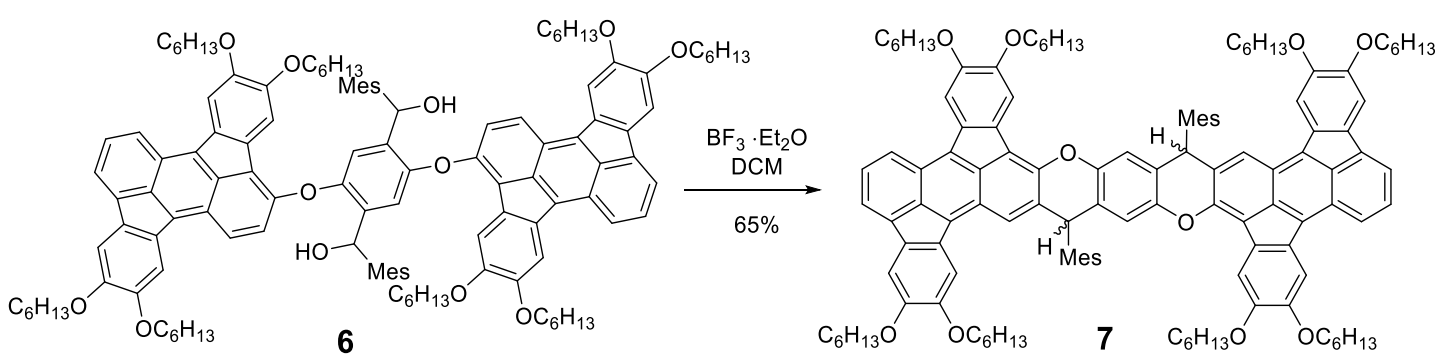

Compound 6 ( $0.13 \mathrm{~g}, 0.07 \mathrm{mmol})$ was added into a dried $250 \mathrm{~mL}$ RBF containing $50 \mathrm{~mL}$ of anhydrous DCM under $\mathrm{N}_{2}$ atmosphere. $\mathrm{BF}_{3} \cdot \mathrm{Et}_{2} \mathrm{O}(0.05 \mathrm{~g}, 1.34 \mathrm{mmol})$ was then added to the reaction mixture upon stirring. The reaction produced a greenish brown solution upon stirring and the reaction was stirred for 30 mins. The reaction progress was monitored using TLC analysis. Thereafter, the reaction mixture was quenched with $20 \mathrm{~mL}$ of $\mathrm{MeOH}$, crude product was washed with $\mathrm{NaCl}$ brine $(3 \times 20 \mathrm{ml})$ and combined organic layer was then dried over anhydrous $\mathrm{Na}_{2} \mathrm{SO}_{4}$. The solvent was then removed, and further purification was 
conducted using column chromatography on silica gel with hexane/DCM (2/1, v/v) as eluent to obtian a brown solid $7(0.082 \mathrm{~g})$ in $65 \%$ yield. The NMR spectra of 7 was not obtained due to the aggregation and low solubility in organic solvents. HRMS (APCI) $\mathrm{m} / \mathrm{z}$ : $[\mathrm{M}+\mathrm{H}]^{+}$calcd for $\mathrm{C}_{126} \mathrm{H}_{147} \mathrm{O}_{10} 1820.0994$; Found 1820.1006 (error $0.7 \mathrm{ppm}$ ).

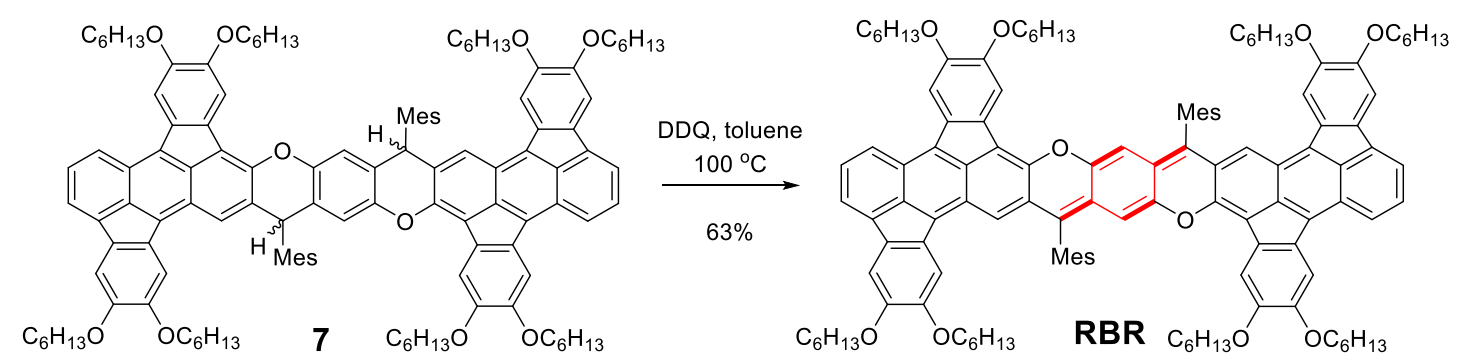

Compound 7 ( $0.07 \mathrm{~g}, 0.04 \mathrm{mmol})$ was added into a dried $250 \mathrm{~mL} \mathrm{RBF}$ containing $50 \mathrm{~mL}$ of anhydrous toluene under $\mathrm{N}_{2}$ atmosphere. DDQ $(0.02 \mathrm{~g}, 0.08 \mathrm{mmol})$ was then added into the reaction mixture upon stirring and heated with an oil bath to $100{ }^{\circ} \mathrm{C}$. The reaction gradually turned from a brown solution to a deep green solution and the reaction was left to run overnight. The reaction progress was monitored using TLC analysis. Thereafter, the crude product was washed with $\mathrm{NaCl}$ brine $(3 \times 20 \mathrm{~mL})$ and combined organic layer was then dried over anhydrous $\mathrm{Na}_{2} \mathrm{SO}_{4}$. The solvent was then removed by rotavap, and further purification was conducted using column chromatography $\left(\mathrm{R}_{\mathrm{f}}=0.7\right.$; $\mathrm{DCM}$ : Hexane, 3:1) to produce a turquoise solid RBR $(0.045 \mathrm{~g})$ in $63 \%$ yield. ${ }^{1} \mathrm{H} \mathrm{NMR}\left(500 \mathrm{MHz}, \mathrm{C}_{6} \mathrm{D}_{6}\right.$, 333K): $\delta(\mathrm{ppm}) 8.43(\mathrm{~d}, J=8.5 \mathrm{~Hz}, 2 \mathrm{H}), 8.10(\mathrm{~s}, 2 \mathrm{H}), 8.05(\mathrm{~s}, 2 \mathrm{H}), 7.90(\mathrm{~s}, 2 \mathrm{H}), 7.59(\mathrm{~d}$, $J=6.5 \mathrm{~Hz}, 2 \mathrm{H}), 7.49(\mathrm{~s}, 2 \mathrm{H}), 7.47-7.44(\mathrm{~m}, 2 \mathrm{H}), 7.39(\mathrm{~s}, 2 \mathrm{H}), 7.16(\mathrm{~s}, 2 \mathrm{H}), 7.12(\mathrm{~s}, 2 \mathrm{H})$, $6.42(\mathrm{~s}, 2 \mathrm{H}), 4.14-4.01(\mathrm{~m}, 8 \mathrm{H}), 4.00-3.97(\mathrm{~m}, 8 \mathrm{H}), 2.50(\mathrm{~s}, 6 \mathrm{H}), 2.26(\mathrm{~s}, 12 \mathrm{H}), 1.97-1.90$ $(\mathrm{m}, 8 \mathrm{H}), 1.89-1.82(\mathrm{~m}, 4 \mathrm{H}), 1.73(\mathrm{~m}, 4 \mathrm{H}), 1.67-1.59(\mathrm{~m}, 8 \mathrm{H}), 1.57-1.46(\mathrm{~m}, 24 \mathrm{H}), 1.40-$ $1.34(\mathrm{~m}, 16 \mathrm{H}), 1.05-1.04(\mathrm{~m}, 12 \mathrm{H}), 1.03-0.93(\mathrm{~m}, 12 \mathrm{H}) .{ }^{13} \mathrm{C} \mathrm{NMR}\left(125 \mathrm{MHz}, \mathrm{C}_{6} \mathrm{D}_{6}\right.$, 333K): $\delta$ (ppm) 151.0, 150.5, 150.0, 149.6, 149.5, 146.4, 139.0, 137.7, 137.6, 135.4, 134.0, 133.6, 133.4, 133.2, 131.5, 131.4, 131.1, 128.8, 128.6, 127.9, 127.7, 127.5, 127.0, 126.4, 123.5, 123.2, 119.6, 119.4, 118.7, 111.8, 111.4, 109.7, 109.6, 103.4, 70.3, 70.1, 69.2, 68.9, 31.91, 31.89, 31.79, 31.72, 30.1, 30.0, 29.88, 29.82, 26.4, 26.1, 26.03, 25.95, 22.8, 22.73, 22.72, 21.2, 19.6, 14.0, 13.9, 13.84, 13.82. HRMS (APCI) m/z: $[\mathrm{M}]^{+}$calcd for $\mathrm{C}_{126} \mathrm{H}_{145} \mathrm{O}_{10}$ 1817.0760; Found 1817.0783 (error 1.3 ppm).

\subsection{Chemical oxidation and reduction of $R B R$}

Typical oxidation procedure to the radical cation of RBR:

Oxidative titration of $\mathbf{R B R}$ was conducted by titrating neutral sample of $\mathbf{R B R}$ with

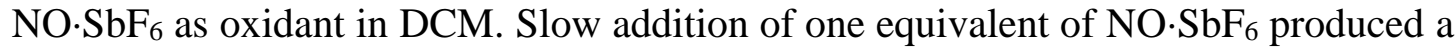
broad absorption signal at $800-1400 \mathrm{~nm}$ with intense absorption at $\lambda_{\max }$ of $1041 \mathrm{~nm}$ as shown in Figure 4b. During this process, the characteristic band of RBR (694 nm)

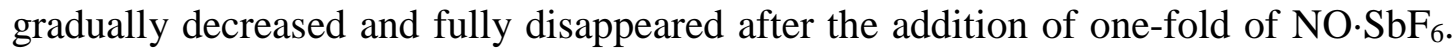
The solution also exhibits a colour change of turquoise in $\mathbf{R B R}$ to light violet of radical 
cation. However, further oxidation of the monoradical cation to its dicaion was unsuccessful since even large amount of $\mathrm{NO}^{-\mathrm{SbF}_{6}}$ was added.

\section{Typical reduction procedure of RBR:}

Sodium anthracenide $(0.02 \mathrm{mmol}$ for dianion) dissolved in $\mathrm{THF}(50 \mu \mathrm{L})$ was added into dry THF solution of RBR $(0.01 \mathrm{mmol}, 1.8 \mathrm{mg}), \mathbf{R B R}^{2-}$ was generated in 2 mins, and the ${ }^{1} \mathrm{H}$ NMR and UV-Vis-NIR spectra were in situ recorded without further purification. ${ }^{1} \mathrm{H}$ NMR (500 MHz, THF- $\left.d_{8}\right): \delta(\mathrm{ppm}) 7.46$ (s, 2H), 7.15 (s, 2H), 7.05 (s, 2H), 6.92 (s, $4 \mathrm{H}), 6.64(\mathrm{~d}, \mathrm{~J}=7.8 \mathrm{~Hz}, 2 \mathrm{H}), 6.48(\mathrm{~s}, 2 \mathrm{H}), 6.28(\mathrm{~d}, \mathrm{~J}=6.8 \mathrm{~Hz}, 2 \mathrm{H}), 6.09$ (t, J = $7.2 \mathrm{~Hz}$, $2 \mathrm{H}), 5.31(\mathrm{~s}, 2 \mathrm{H}), 5.00(\mathrm{~s}, 2 \mathrm{H})$. The protons in alkyl chain region could not be identified due to the overlap of signals with the peaks from THF- $d_{8}$ solvent. However, the protons from aromatic region could be assigned by 2D NOESY technique as shown in Figure $\mathrm{S} 15$, and the ingetrations were obtained based on it.

\subsection{Method for the crystal growth of RBR}

Single crystals of RBR suitable for X-ray crystallography analysis were obtained by slow diffusion of $n$-hexane into THF solution. AR grade $n$-Hexane and HPLC grade THF from commercial source were used without further purification. Preparation of RBR crystals were conducted by dissolving RBR solid in THF solvent (about $1 \mathrm{mM}$ ) under ambient conditions, layering it with $n$-hexane thereafter. The resulting mixture was left uninterrupted for slow diffusion to occur. Turquoise crystals were observed after one week and were ready for X-ray crystallographic analysis.

\section{Additional data}

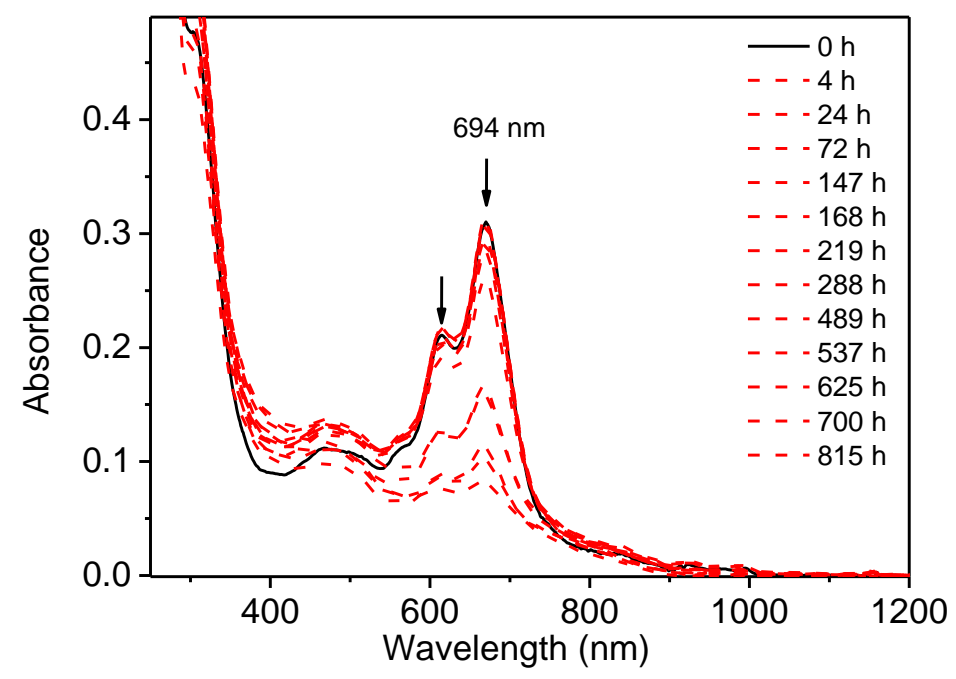

Figure S1. Changes of absorption spectra of RBR in dry DCM $\left(\sim 3 \times 10^{-5} \mathrm{M}\right)$ under ambient light and air conditions. 
Table S1. Electrochemical and optical data of RBR in DCM

\begin{tabular}{|c|c|c|c|c|c|c|c|c|}
\hline Com. & $\begin{array}{c}E_{1 / 2}{ }^{\mathrm{red}} \\
(\mathrm{V})^{\mathrm{a}}\end{array}$ & $\begin{array}{c}E_{1 / 2}{ }^{o x} \\
(V)^{a}\end{array}$ & $\begin{array}{c}\text { HOMO } \\
(\mathrm{eV})\end{array}$ & $\begin{array}{c}\text { LUMO } \\
(\mathrm{eV})\end{array}$ & $\begin{array}{l}E_{\mathrm{g}} \mathrm{CV} \\
(\mathrm{eV})\end{array}$ & $\begin{array}{c}\lambda_{a b s} \\
(\mathbf{n m})\end{array}$ & $\begin{array}{c}\mathcal{E}_{\max } \\
\left(\mathrm{cm}^{-1} \mathbf{M}^{-1}\right)\end{array}$ & $\begin{array}{l}E_{\mathrm{g}}{ }^{\mathrm{ppt}} \\
(\mathrm{eV})\end{array}$ \\
\hline RBR & $\begin{array}{l}-1.33 \\
-1.48\end{array}$ & 0.31 & -5.14 & -3.63 & 1.51 & $\begin{array}{l}644(\mathrm{sh}) \\
694(\mathrm{~m})\end{array}$ & $7.14 \times 10^{4}$ & 1.65 \\
\hline
\end{tabular}

Note: $E_{1 / 2}^{\text {red }}$ and $E_{1 / 2}{ }^{\text {ox }}$ are the half-wave potentials for respective oxidation and reduction waves with $\mathrm{Fc}^{+} / \mathrm{Fc}$ as reference. Electrochemical HOMO and LUMO energy levels were calculated from the onset values of oxidation and reduction potentials. $E_{\mathrm{g}} \mathrm{CV}$ is the electrochemical energy gap derived from LUMO-HOMO. $\lambda_{\text {abs: }}$ main absorption peak, m: main peak, sh: shoulder peak. $\varepsilon_{\max }$ : molar extinction coefficient at the absorption maximum. $E_{\mathrm{g}}{ }^{\text {opt }}$ : optical energy gap calculated from onset of the absorption maximum.

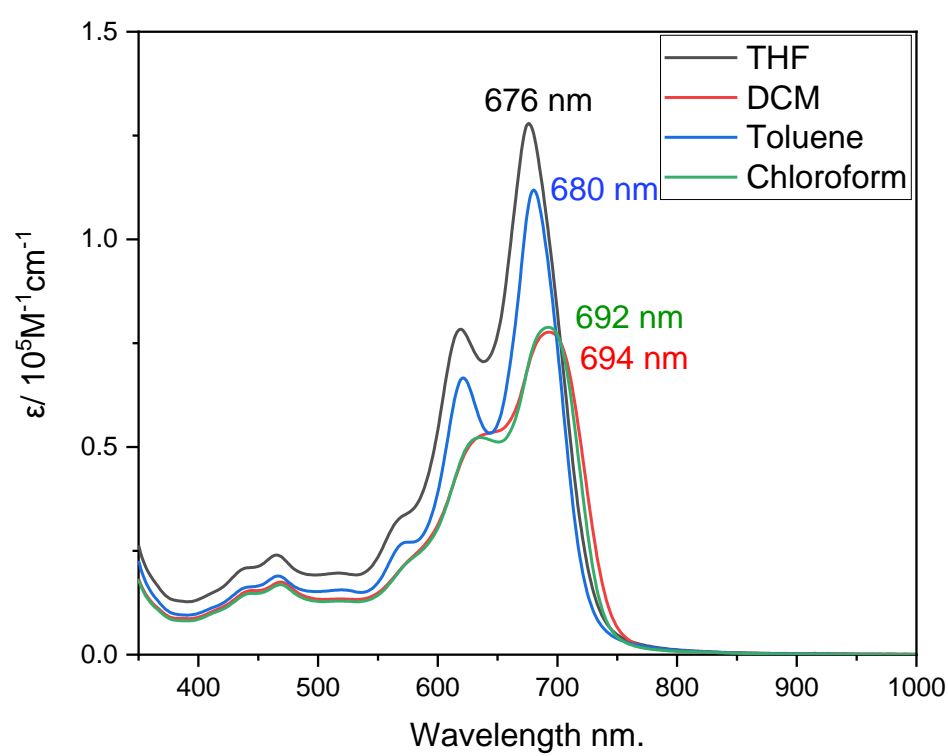

Figure S2. The UV-vis absorption spectra of RBR $\left(1 \times 10^{-5} \mathrm{M}\right)$ in four different solvents (DCM, chloroform, THF and toluene).

It exhibited a solvatochromic shift range of about $18 \mathrm{~nm}$. The frontier orbital profiles were also calculated by DFT method (see Figure S3) and it is observed that the HOMO orbital lobes are more apparent in the central part of the backbone and slightly extended to the lateral anthracene, while the LUMO orbital lobes are generally distributed on the entire backbone and further extended to the cyclopenta rings. From this, we can suggest that it is possible for a weak intramolecular charge transfer between the electron-rich backbone and the electron-deficient cyclopenta rings which is influenced by the polarity of the solvents used. 


\section{DFT calculations}

Density functional theory calculations were employed with Gaussian 09 package, ${ }^{1}$ utilizing the B3LYP or UCAM-B3LYP ${ }^{2-6}$ level of theory with Pople basis set 6$31 \mathrm{G}(\mathrm{d}, \mathrm{p})^{5-7}$ for all neutral molecules in the gas phase. Natural orbital occupation number (NOON)) calculations were done by spin unrestricted UCAM-B3LYP/6$31 \mathrm{G}(\mathrm{d}, \mathrm{p})$ method and the diradical character $\left(y_{0}\right)$ was calculated according to Yamaguchi's scheme: $y_{0}=1-\left(2 T /\left(1+T^{2}\right)\right)$, and $T=\left(n_{\mathrm{HOMO}}-n_{\mathrm{LUMO}}\right) / 2\left(n_{\mathrm{HOMO}}\right.$ is the

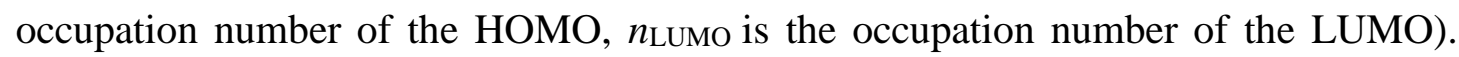
NICS values were calculated using the standard GIAO procedure $\left(\right.$ NMR pop $=$ NCSall). ${ }^{8}$ ACID plots were calculated by using the method developed by Herges. ${ }^{9}$

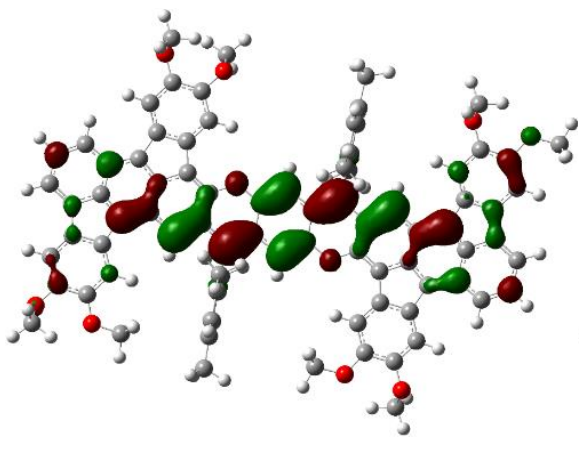

HOMO: $-4.68 \mathrm{eV}$

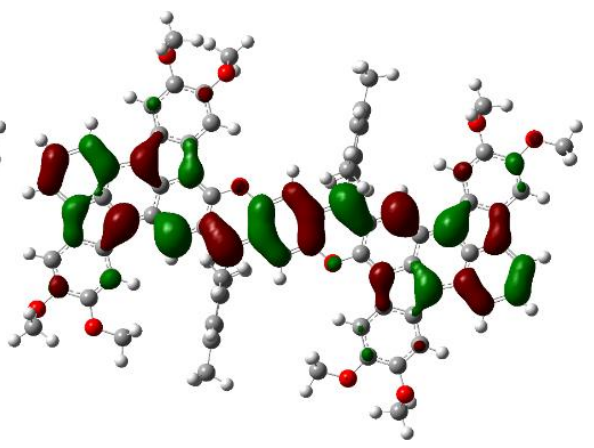

LUMO: $-2.89 \mathrm{eV}$

Figure S3. Frontier orbital profiles HOMO (left) and LUMO (right) of RBR calculated by DFT mehod at B3LYP/6-31G(d,p) level. Hexyloxy groups are replaced by methoxy groups for ease of calculation.

Table S2. Calculated diradical character $y_{0}$ and singlet-triplet energy band gap $\Delta E_{\text {S-T }}$ for the neutral compounds at the UCAM-B3LYP/6-31G(d,p) level. Both suggest a substantial closed-shell nature.

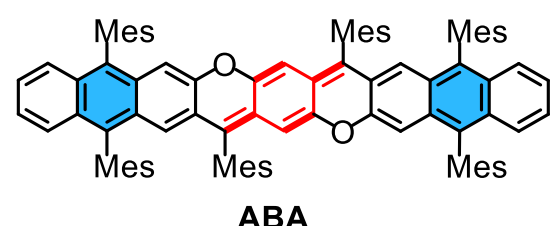

ABA

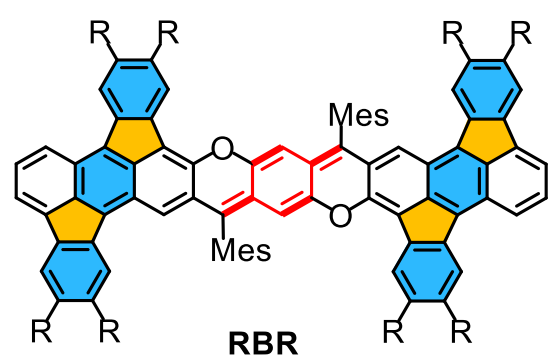

RBR
Compound

ABA

RBR $y_{0}$

$\Delta E_{\mathrm{S}-\mathrm{T}}(\mathrm{Kcal} / \mathrm{mol})$

\begin{tabular}{ccc}
\hline ABA & 0.007 & -13.4 \\
RBR & 0.013 & -12.5 \\
\hline
\end{tabular}



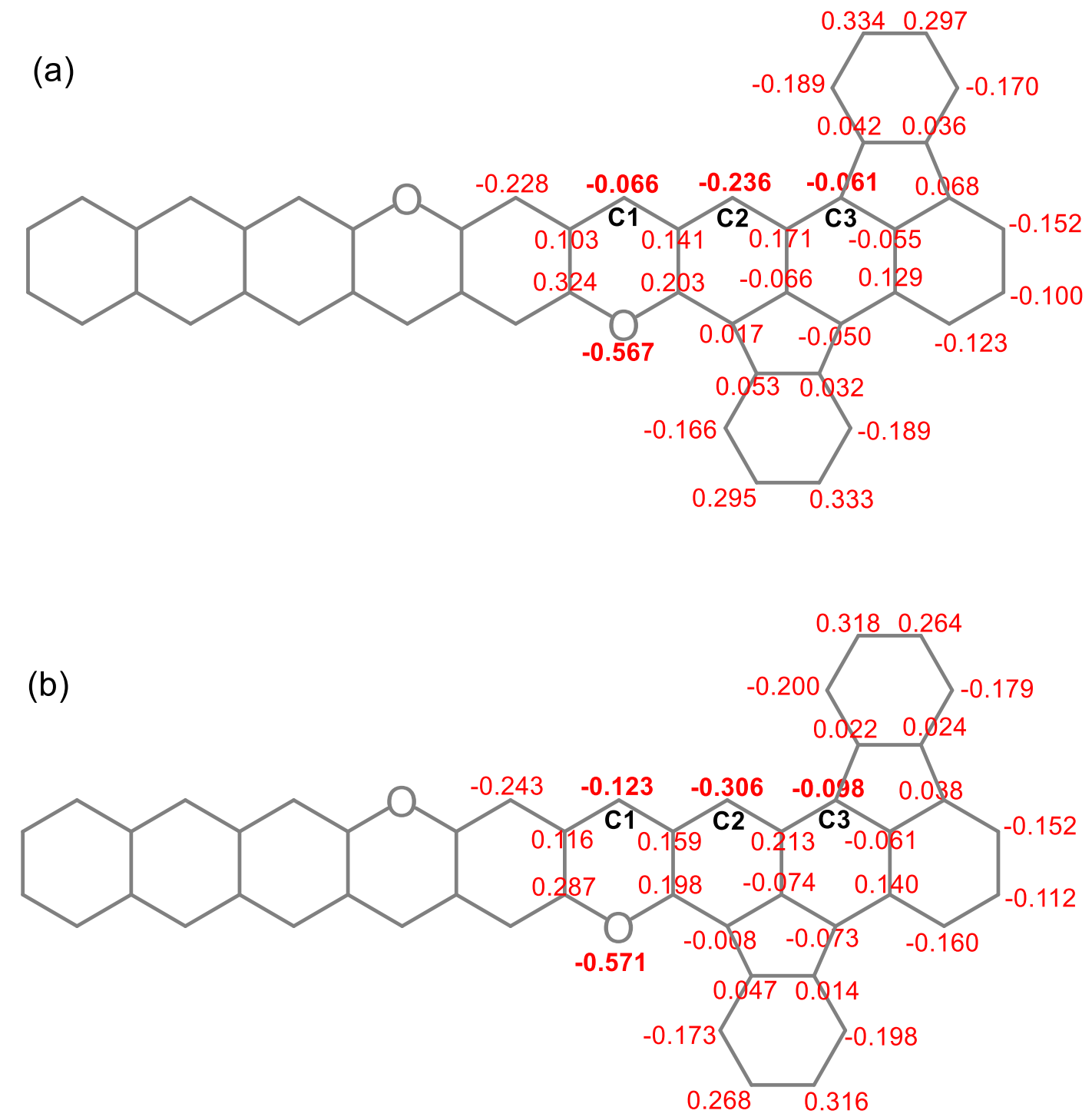

Figure S4. Calculated mulliken charge distribution maps of (a) $\mathbf{R B R}$ and (b) $\mathbf{R B R}^{\mathbf{2}-}$ (B3LYP/6-31G (d, p)). 
Table S3. DFT calculated NICS(1) $)_{z z}$ values of $\mathbf{R B R}$ and $\mathbf{R B R}^{2-}$ at B3LYP/6-31G(d, p) level.

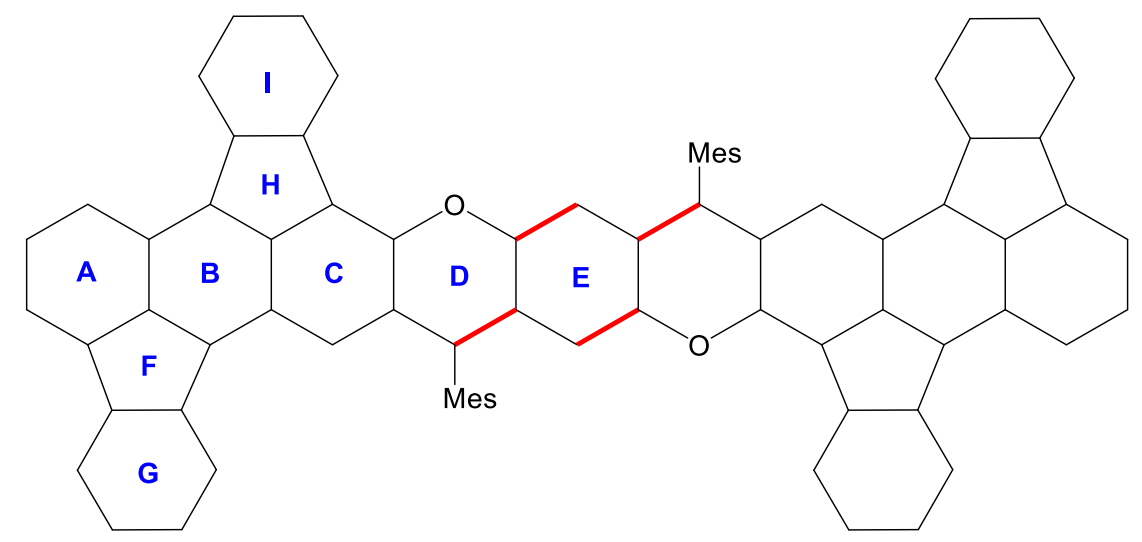

\begin{tabular}{llllllllll}
\hline & Ring A & Ring B & Ring C & Ring D & Ring E & Ring F & Ring G & Ring H & Ring I \\
\hline RBR & -17.92 & -20.50 & -13.21 & 8.39 & 0.62 & 14.35 & -17.17 & 9.24 & -18.47 \\
\hline $\mathbf{R B R}^{2-}$ & -20.91 & -0.31 & 0.99 & 9.18 & -9.97 & -6.32 & -22.18 & -6.61 & -23.18 \\
\hline
\end{tabular}

(a)
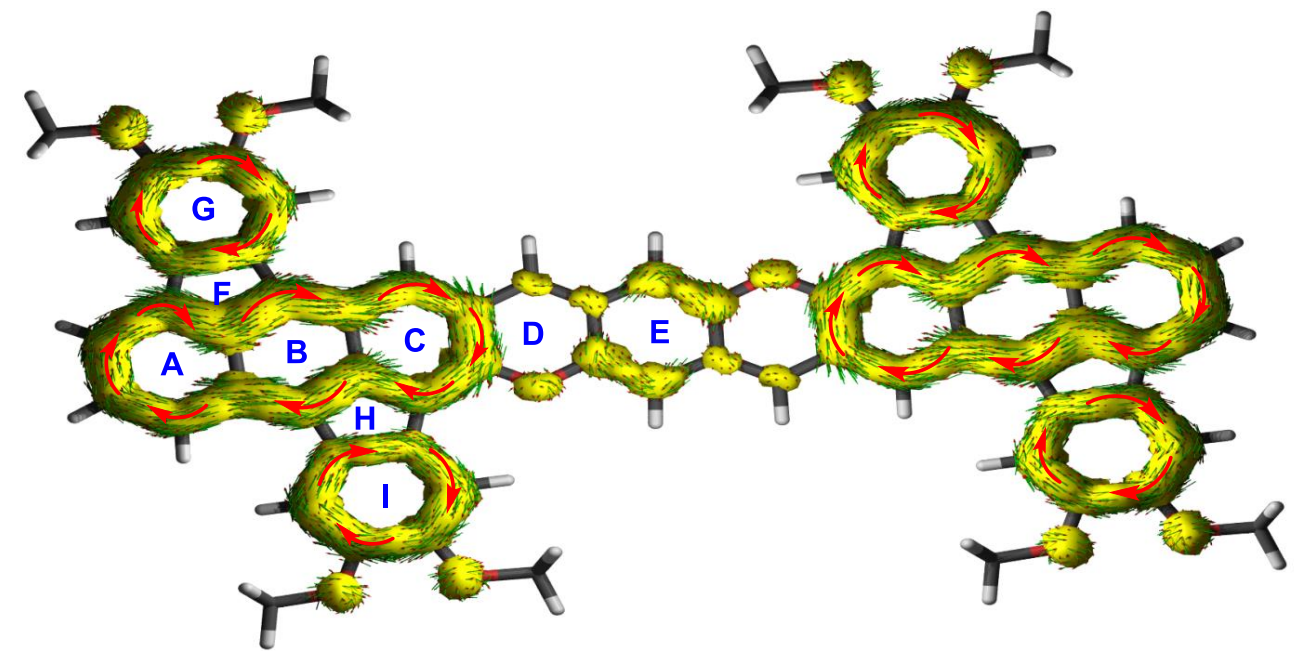

(b)

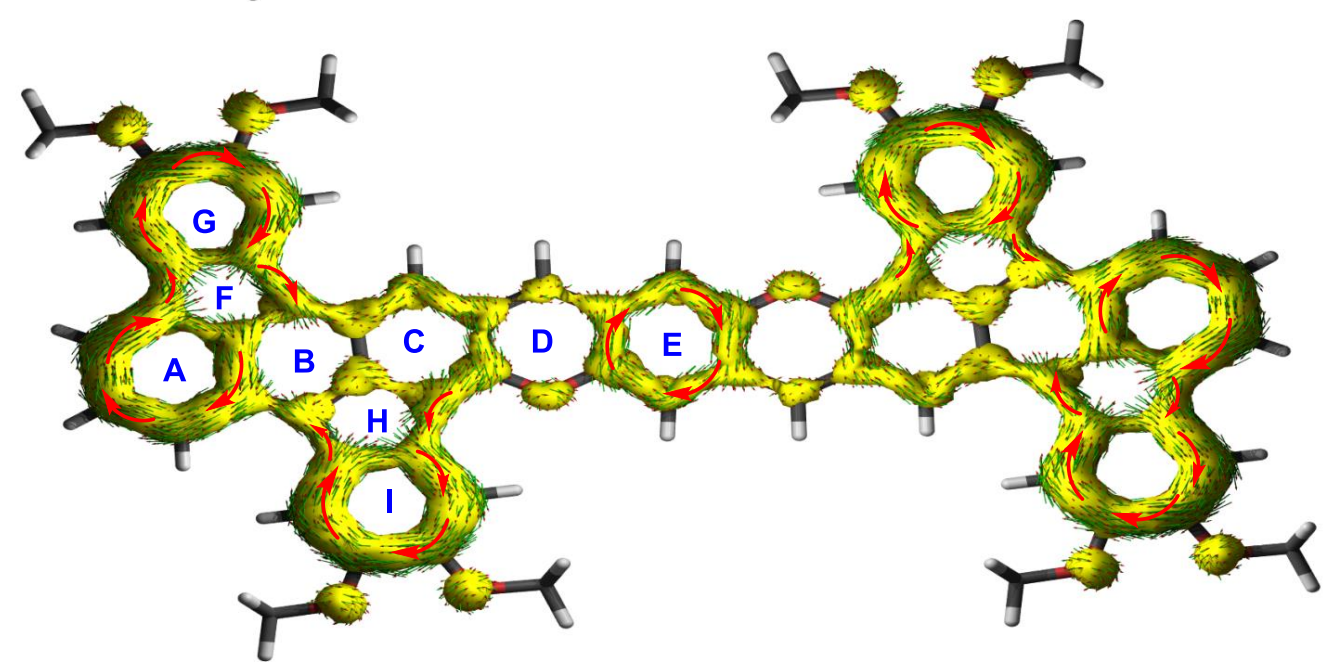

Figure S5. Calculated ACID plots of (a) RBR and (b) BRR ${ }^{2-}$ at B3LYP/6-31G(d,p) level. 


\section{References:}

1. Gaussian 09; Revision A.2; Frisch, M. J.; Trucks, G. W.; Schlegel, H. B.; Scuseria, G. E.; Robb, M. A.; Cheeseman, J. R.; Scalmani, G.; Barone, V.; Mennucci, B.;

Petersson, G. A.; Nakatsuji, H.; Caricato, M.; Li, X.; Hratchian, H. P.; Izmaylov, A. F.; Bloino, J.; Zheng, G.; Sonnenberg, J. L.; Hada, M.; Ehara, M.; Toyota, K.;

Fukuda, R.; Hasegawa, J.; Ishida, M.; Nakajima, T.; Honda, Y.; Kitao, O.; Nakai, H.; Vreven, T.; Montgomery, J., J. A.; Peralta, J. E.; Ogliaro, F.; Bearpark, M.; Heyd, J. J.; Brothers, E.; Kudin, K. N.; Staroverov, V. N.; Kobayashi, R.; Normand, J.; Raghavachari, K.; Rendell, A.; Burant, J. C.; Iyengar, S. S.; Tomasi, J.; Cossi, M.; Rega, N.; Millam, N. J.; Klene, M.; Knox, J. E.; Cross, J. B.; Bakken, V.; Adamo, C.; Jaramillo, J.; Gomperts, R.; Stratmann, R. E.; Yazyev, O.; Austin, A. J.; Cammi, R.; Pomelli, C.; Ochterski, J. W.; Martin, R. L.; Morokuma, K.; Zakrzewski, V. G.; Voth, G. A.; Salvador, P.; Dannenberg, J. J.; Dapprich, S.; Daniels, A. D.; Farkas, Ö.;

Foresman, J. B.; Ortiz, J. V.; Cioslowski, J.; Fox, D. J.; Gaussian, Inc., Wallingford CT, 2009.

2. Becke, A. D. J. Chem. Phys. 1993, 98, 5648.

3. Lee, C.; Yang, W.; Parr, R. G. Phys. Rev. B: Condens. Matter 1988, 37, 785.

4. Yanai, T.; Tew, D.; and Handy, N. Chem. Phys. Lett. 2004, 393, 51.

5. Ditchfield, R.; Hehre, W. J.; Pople, J. A. J. Chem. Phys. 1971, 54, 724.

6. Hehre, W. J.; Ditchfield R.; Pople, J. A. J. Chem. Phys. 1972, 56, 2257.

7. Hariharan, P. C.; Pople, J. A. Theor. Chim. Acta 1973, 28, 213.

8. Fallah-Bagher-Shaidaei, H.; Wannere, S. S.; Corminboeuf, C.; Puchta, R.; Schleyer, P. v. R. Org. Lett. 2006, 8, 863.

9. Geuenich, D.; Hess, K.; Köhler, F.; Herges, R. Chem. Rev. 2005, 105, 3758. 


\section{Appendix I: Crystallographic data}

Empirical formula
Formula weight
Temperature
Wavelength
Crystal system
Space group

Unit cell dimensions

Volume

Z

Density (calculated)

Absorption coefficient

$\mathrm{F}(000)$

Crystal size

Theta range for data collection

Index ranges

Reflections collected

Independent reflections

Completeness to theta $=66.596^{\circ}$

Absorption correction

Max. and min. transmission

Refinement method

Data / restraints / parameters

Goodness-of-fit on $\mathrm{F}^{2}$

Final R indices [I $>2 \operatorname{sigma}(\mathrm{I})]$

$\mathrm{R}$ indices (all data)

Extinction coefficient

Largest diff. peak and hole
$\mathrm{C}_{126} \mathrm{H}_{144} \mathrm{O}_{10}(\mathrm{THF})_{0.5}$

1854.46

100(2) K

$1.54178 \AA$

Triclinic

$\mathrm{P}-1$

$\mathrm{a}=16.2022(9) \AA$

$\mathrm{a}=113.770(3)^{\circ}$.

$\mathrm{b}=17.2872(10) \AA$

$\mathrm{b}=95.229(3)^{\circ}$.

$\mathrm{c}=20.9068(12) \AA$

$\mathrm{g}=101.861(3)^{\circ}$.

5144.7(5) $\AA^{3}$

2

$1.197 \mathrm{Mg} / \mathrm{m}^{3}$

$0.575 \mathrm{~mm}^{-1}$

2000

$0.299 \times 0.139 \times 0.090 \mathrm{~mm}^{3}$

2.354 to $66.596^{\circ}$.

$-19<=\mathrm{h}<=19,-20<=\mathrm{k}<=20,-24<=\mathrm{l}<=24$

113686

$18128[\mathrm{R}($ int $)=0.0681]$

$99.8 \%$

Semi-empirical from equivalents

0.7533 and 0.6931

Full-matrix least-squares on $\mathrm{F}^{2}$

18128 / $776 / 1461$

1.012

$\mathrm{R} 1=0.0552, \mathrm{wR} 2=0.1339$

$\mathrm{R} 1=0.0777, \mathrm{wR} 2=0.1481$

$\mathrm{n} / \mathrm{a}$

0.815 and -0.410 e. $\AA^{-3}$

Note: The crystal is triclinic space group P-1. The asymmetric unit contains one molecule of the compound $\mathrm{C}_{126} \mathrm{H}_{144} \mathrm{O}_{10}$ and half a THF. Three of the long linear chains (two $\mathrm{C}_{6} \mathrm{H}_{13}$ and one $\mathrm{OC}_{6} \mathrm{H}_{13}$ ) were disordered into two positions with occupancy ratios $=69: 31,59: 41$ and 48:52. The THF is also disordered with occupancy ratio=50:50. Restraints in bond lengths and thermal parameters were applied to the disordered atoms. 
(a)

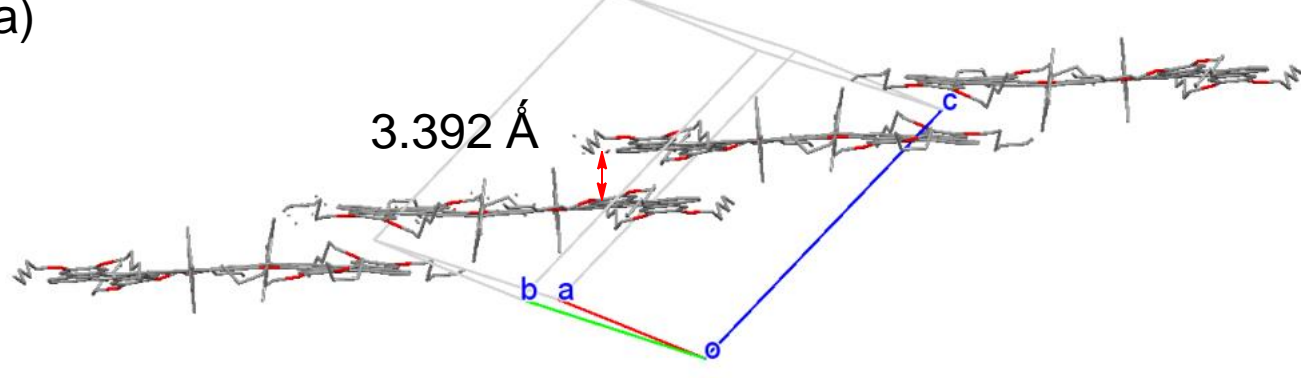

(b)

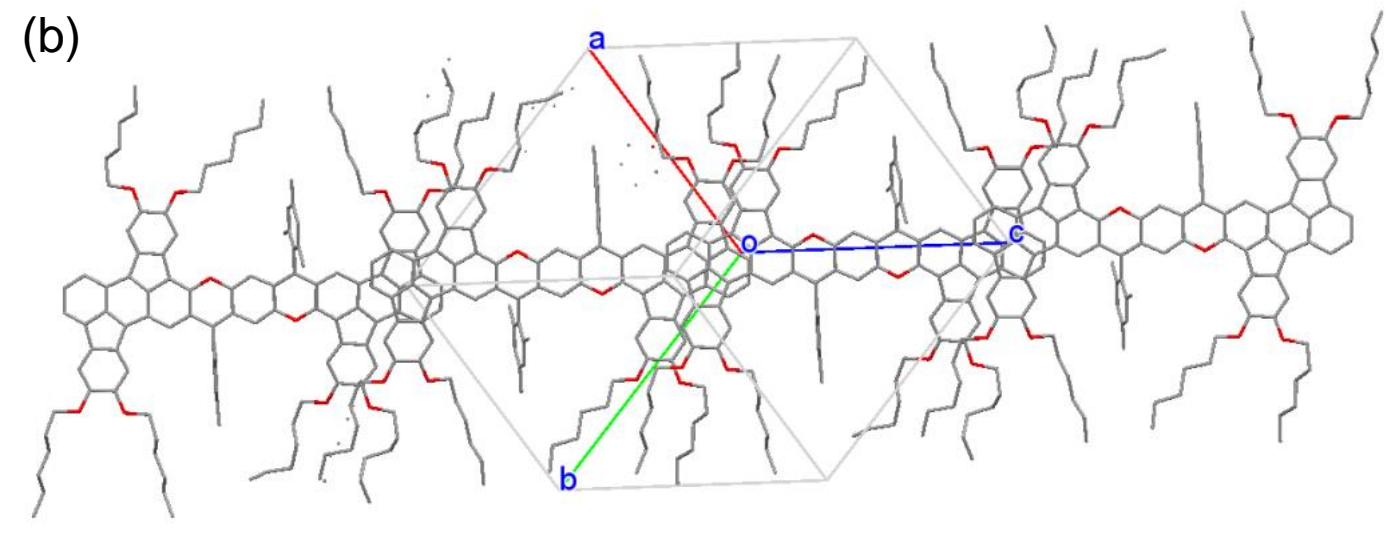

Figure S6. Packing motifs of RBR in single crystal of (a) side view and (b) top view. 


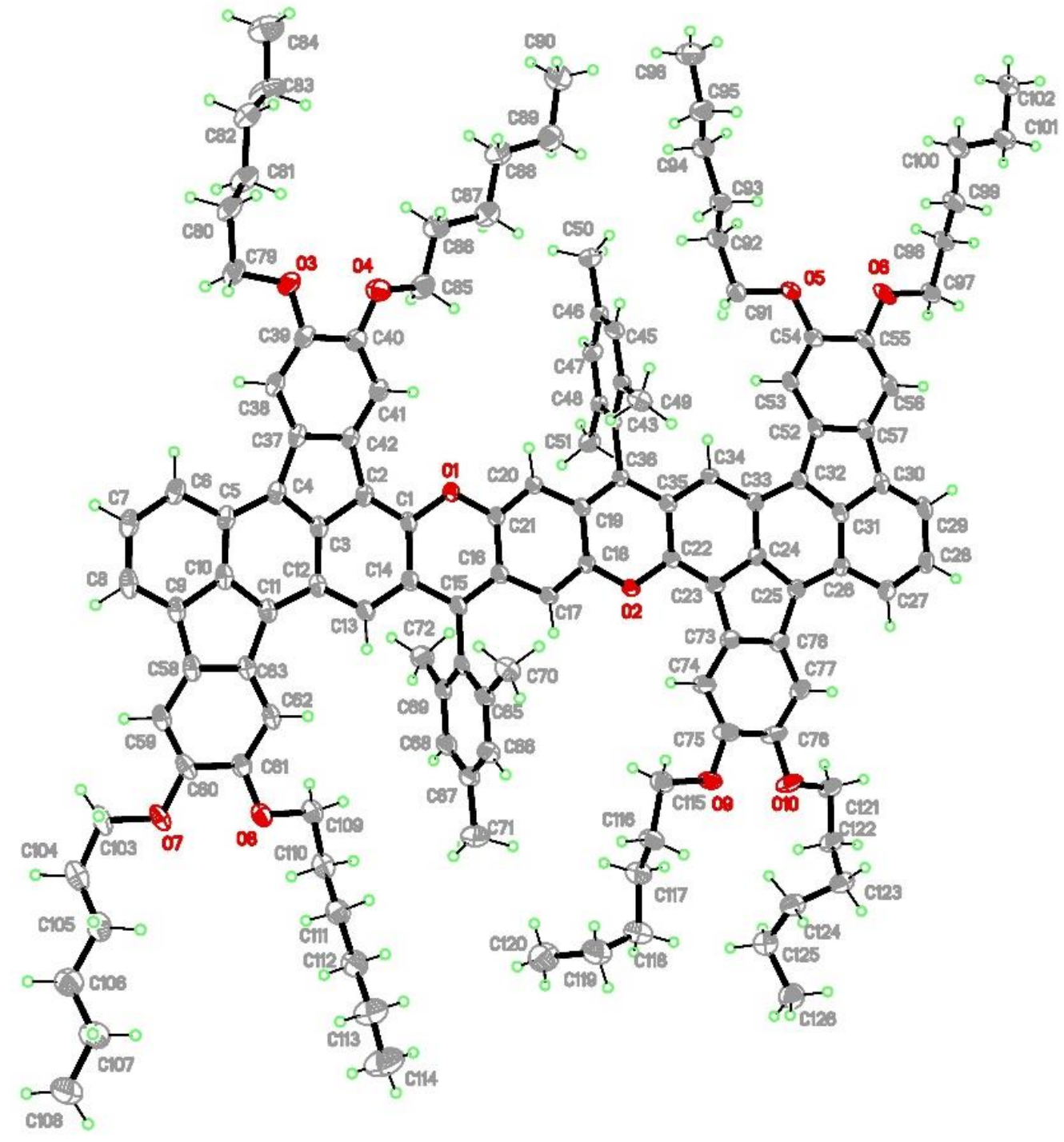

Figure S7. Thermal ellipsoid plot of the crystal structure of RBR. The thermal ellipsoids shown at $50 \%$ probability. 


\section{Appendix II: ${ }^{1} \mathrm{H}$ NMR and ${ }^{13} \mathrm{C}$ NMR spectra of all new compounds}

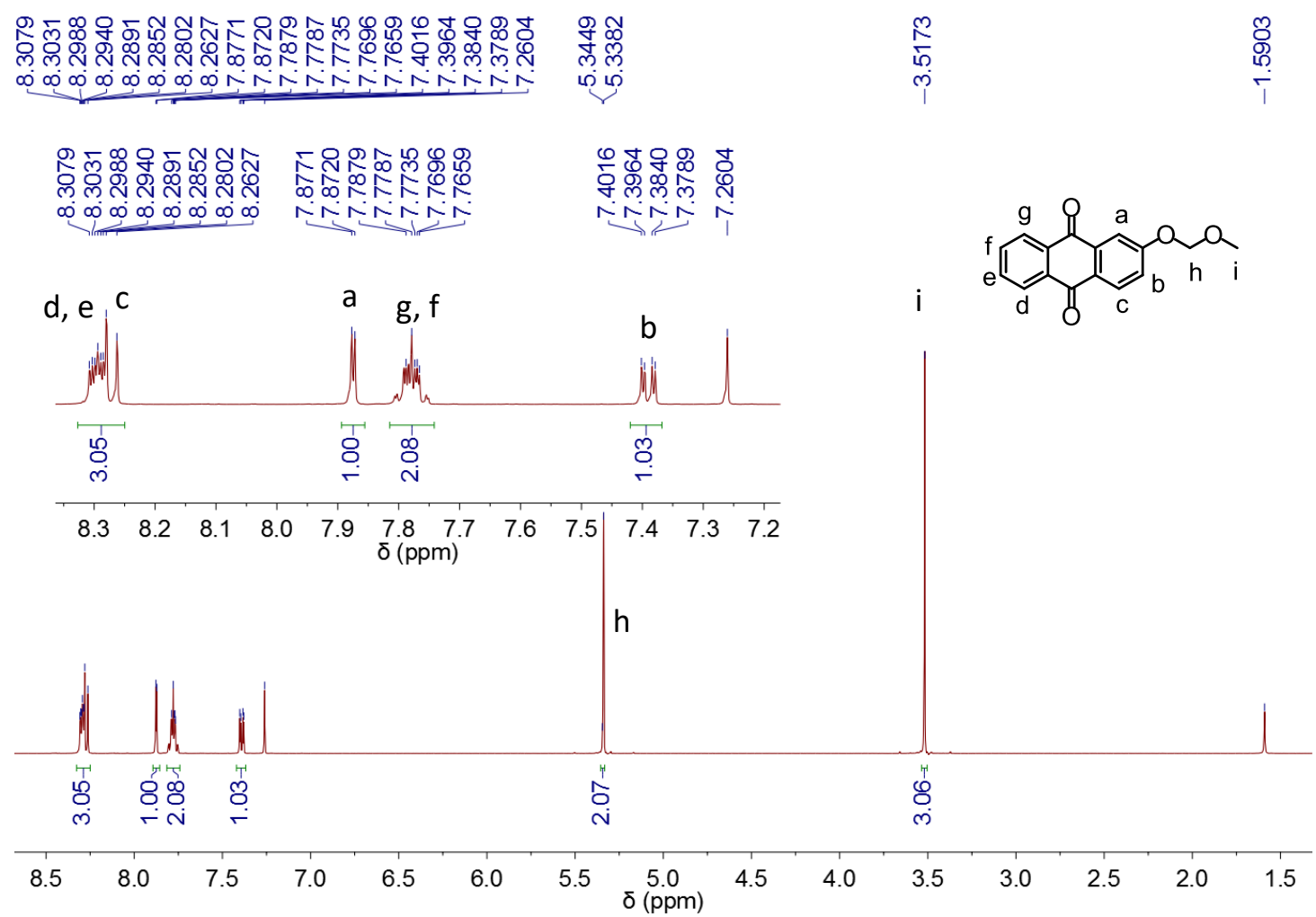

Figure S8. ${ }^{1} \mathrm{H}$ NMR spectrum of $1\left(500 \mathrm{MHz}, \mathrm{CDCl}_{3}\right)$.

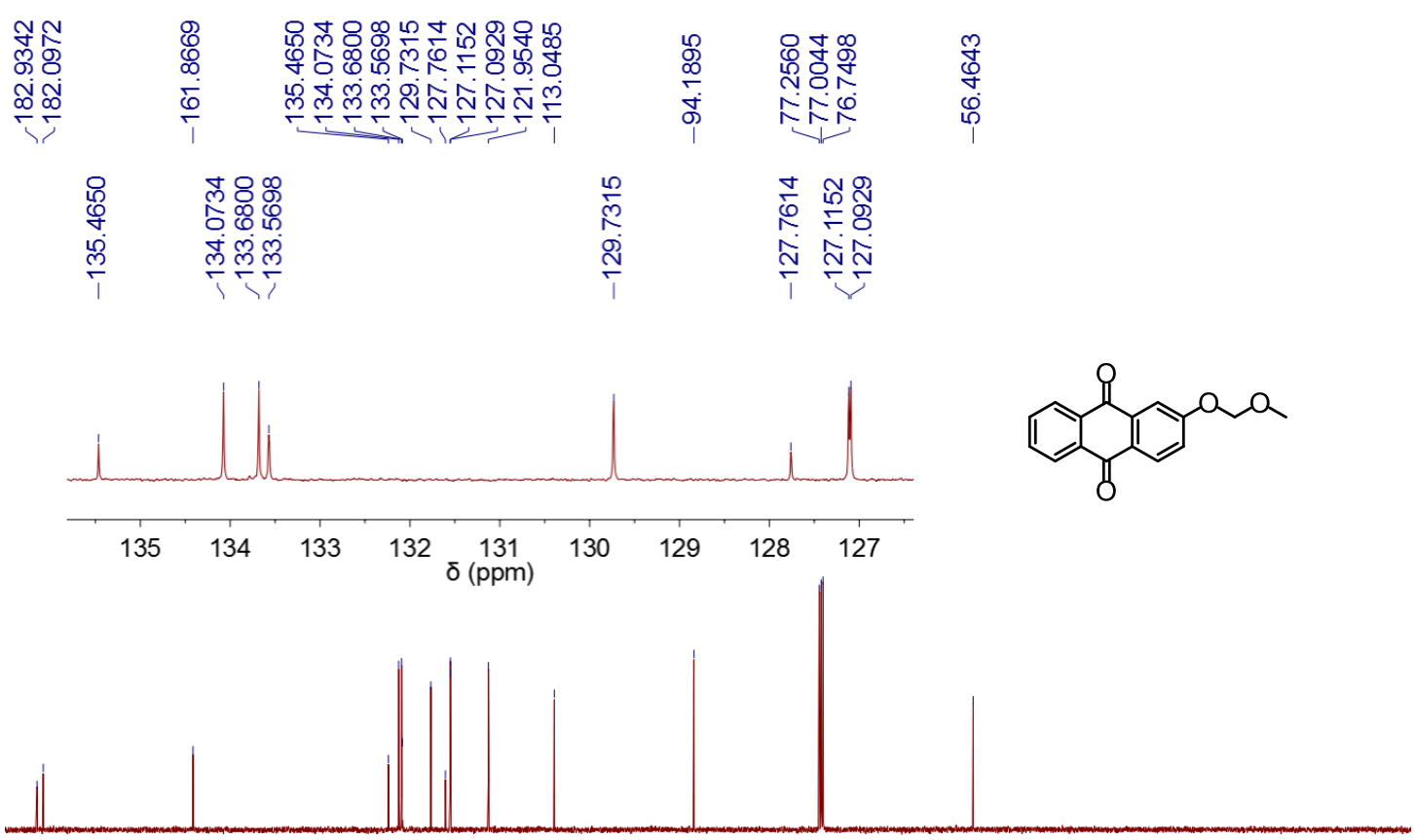

$\begin{array}{lllllllllllllllllll}180 & 170 & 160 & 150 & 140 & 130 & 120 & 110 & 100 \underset{\delta(\mathrm{ppm})}{90} & 80 & 70 & 60 & 50 & 40 & 30 & 20 & 10 & 0\end{array}$

Figure S9. ${ }^{13} \mathrm{C} \mathrm{NMR}$ spectrum of $1\left(125 \mathrm{MHz}, \mathrm{CDCl}_{3}\right)$. 


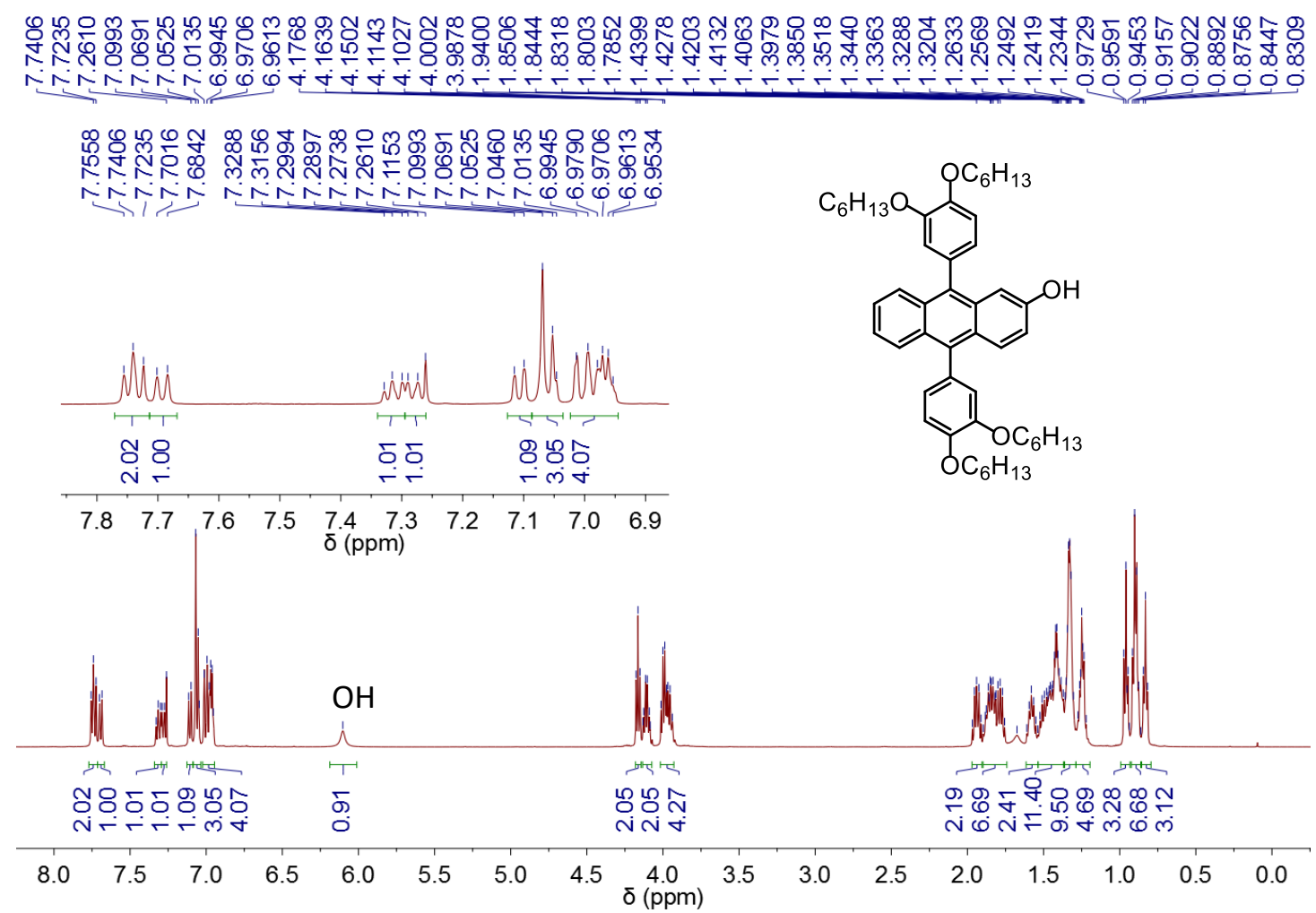

Figure S10. ${ }^{1} \mathrm{H}$ NMR spectrum of $2\left(500 \mathrm{MHz}, \mathrm{CDCl}_{3}\right)$.

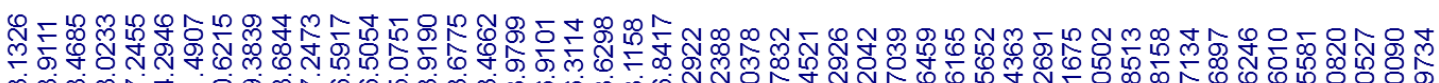

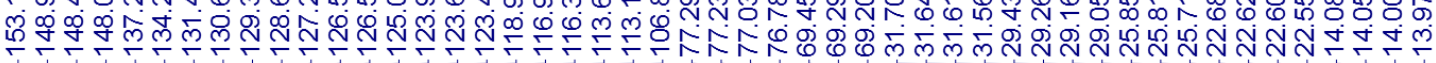

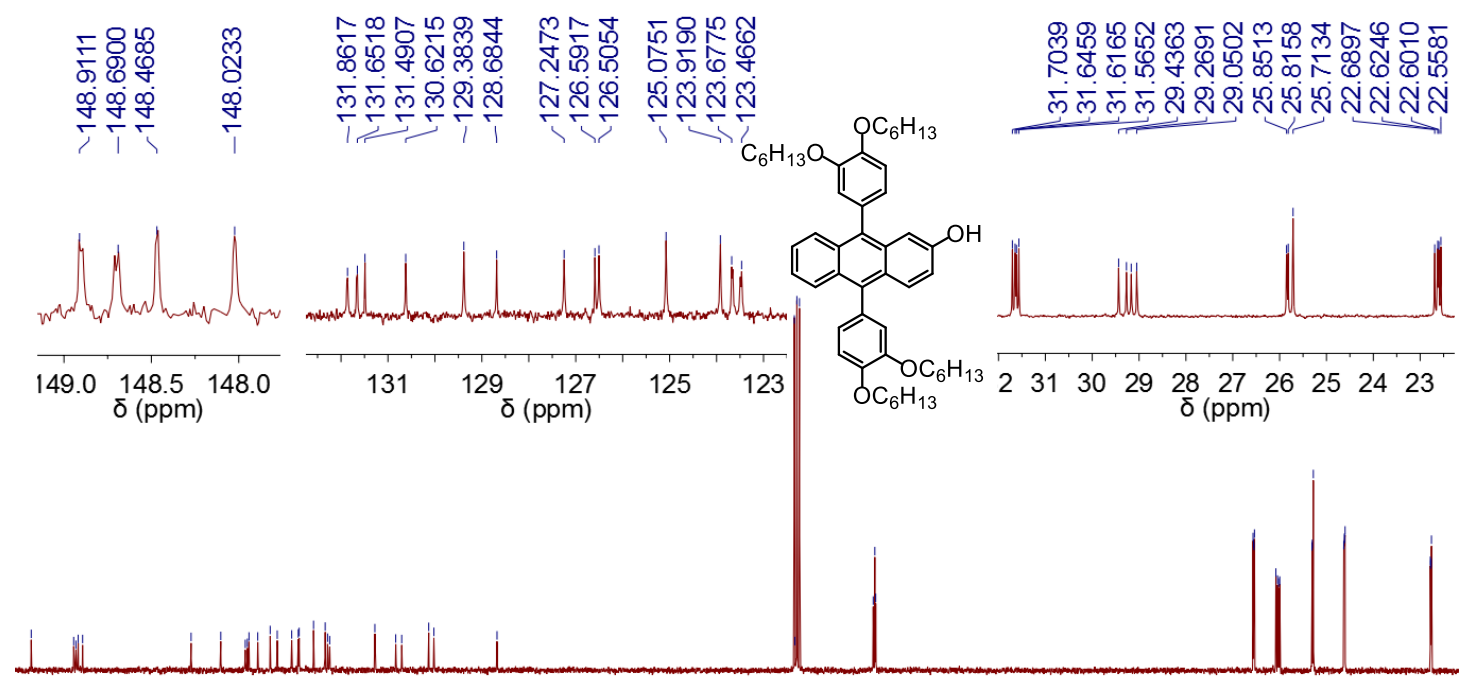

$15014514013513012512011511010510095 \quad 90 \begin{array}{r}85 \\ \delta(\mathrm{ppm})\end{array}$

Figure S11. ${ }^{13} \mathrm{C}$ NMR spectrum of $2\left(125 \mathrm{MHz}, \mathrm{CDCl}_{3}\right)$. 


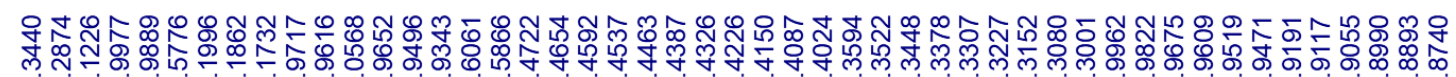
N Ní

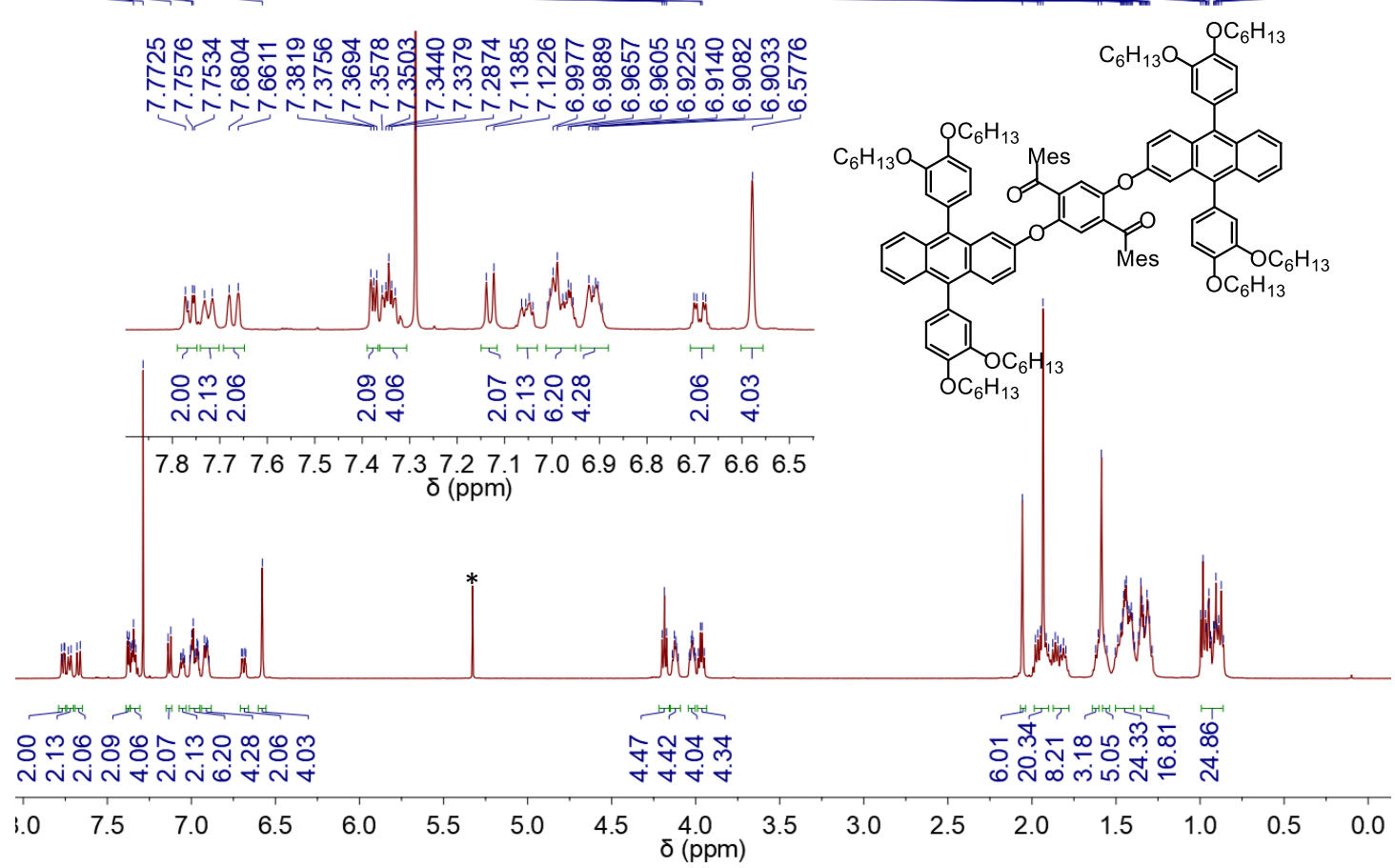

Figure S12. ${ }^{1} \mathrm{H}$ NMR spectrum of $4\left(500 \mathrm{MHz}, \mathrm{CDCl}_{3}\right)$. The peak labeled by * is from residual DCM.

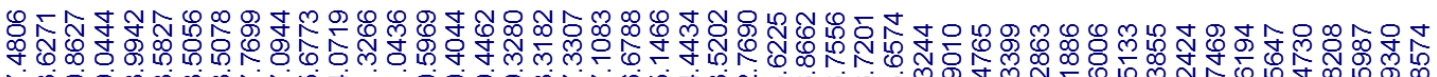

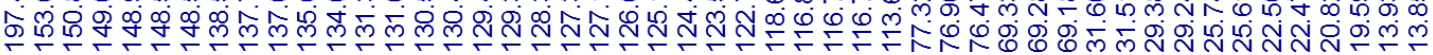

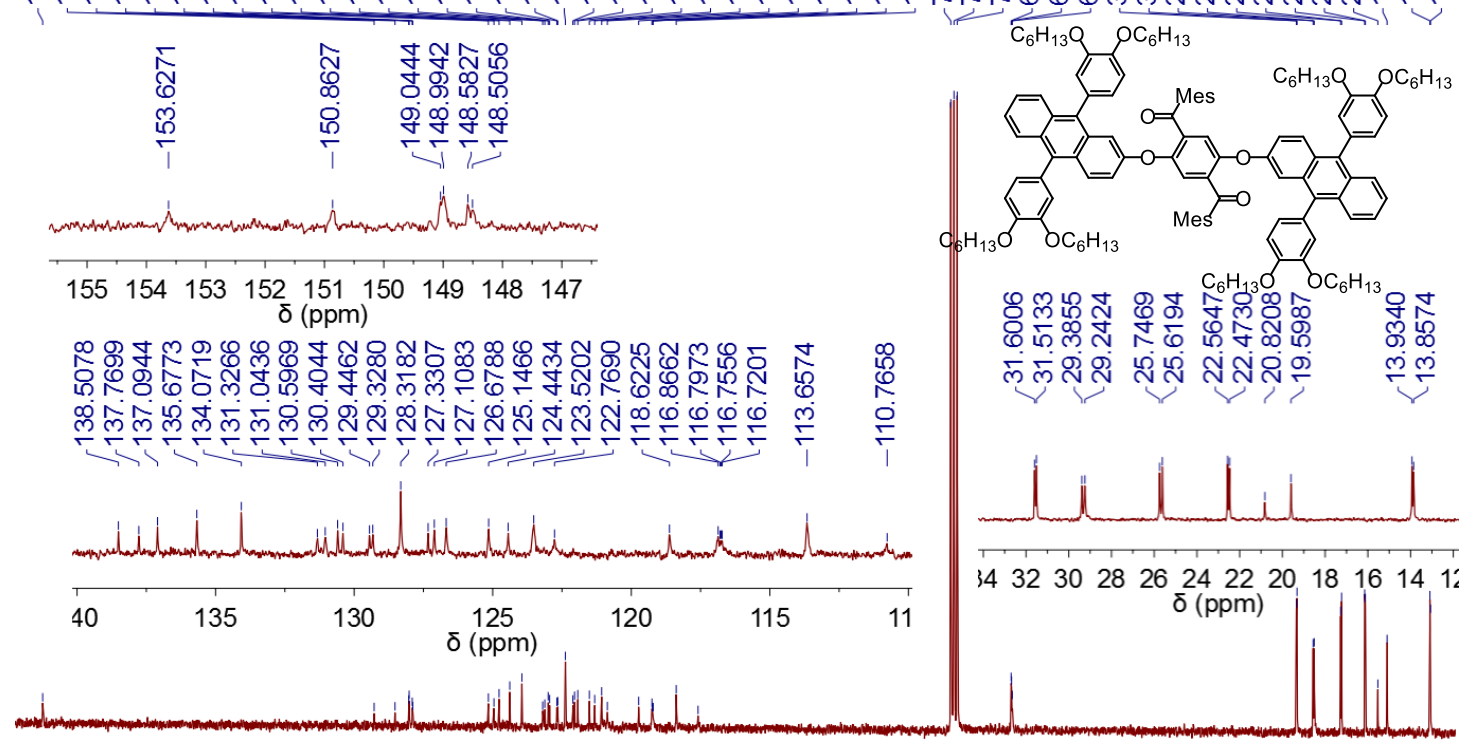

$\begin{array}{lllllllllllllllllll}00 & 190 & 180 & 170 & 160 & 150 & 140 & 130 & 120 & \begin{array}{c}110 \\ \delta(\mathrm{ppm})\end{array} & 90 & 80 & 70 & 60 & 50 & 40 & 30 & 20\end{array}$

Figure S13. ${ }^{13} \mathrm{C}$ NMR spectrum of $4\left(125 \mathrm{MHz}, \mathrm{CDCl}_{3}\right)$. 


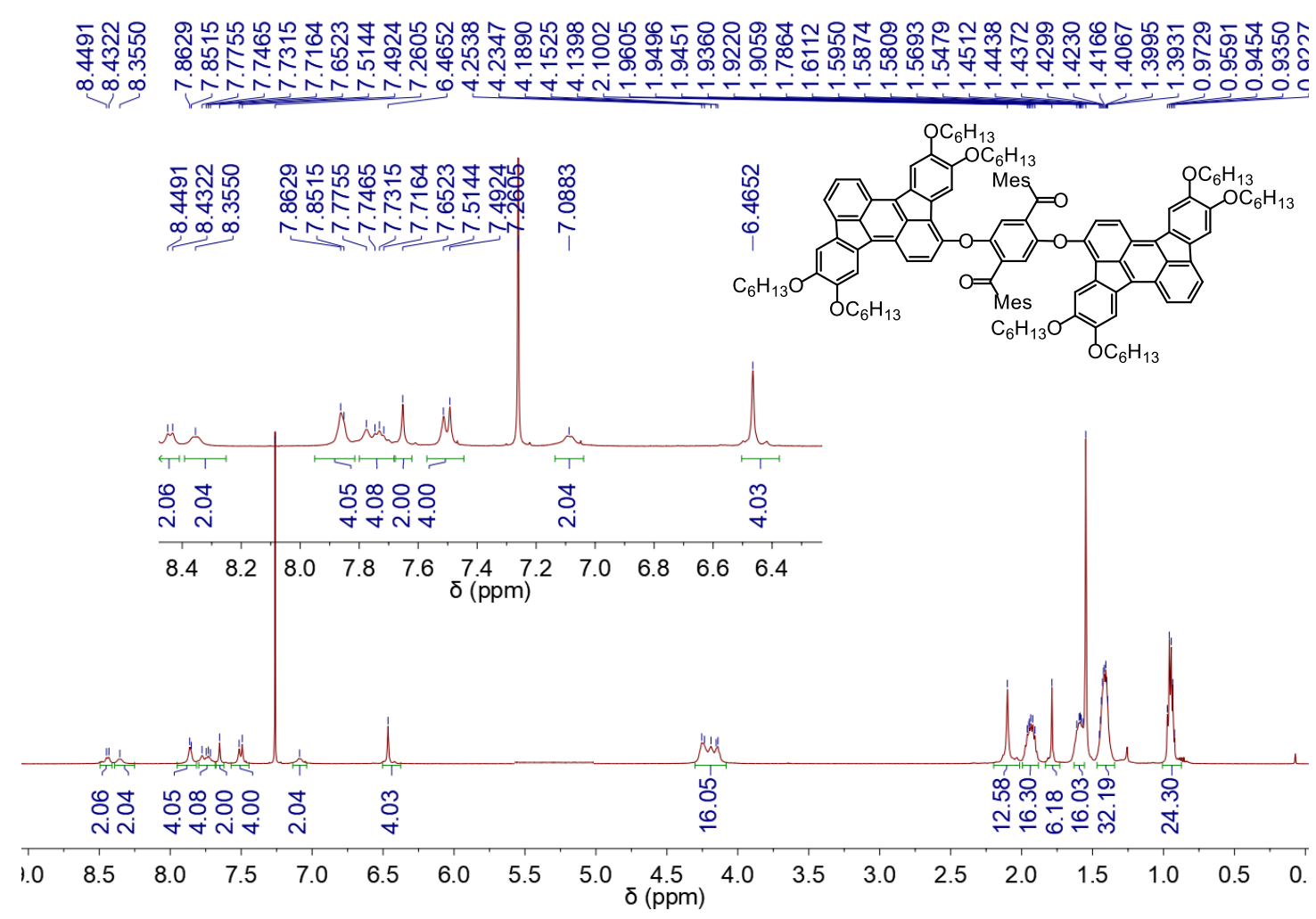

Figure S14. ${ }^{1} \mathrm{H}$ NMR spectrum of $5\left(500 \mathrm{MHz}, \mathrm{CDCl}_{3}\right)$.

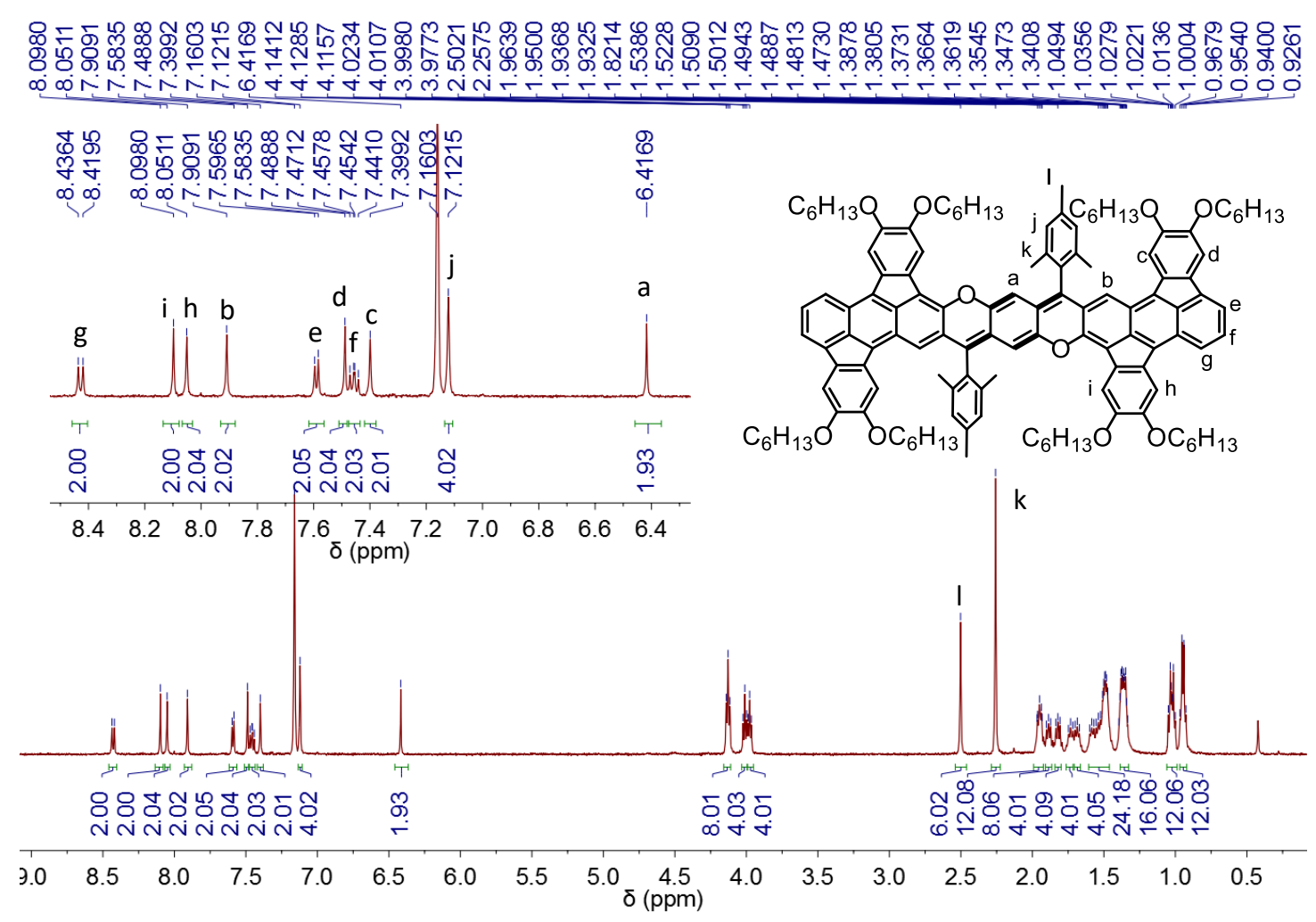

Figure S15. ${ }^{1} \mathrm{H}$ NMR spectrum of RBR $\left(500 \mathrm{MHz}, \mathrm{C}_{6} \mathrm{D}_{6}, 333 \mathrm{~K}\right)$. 


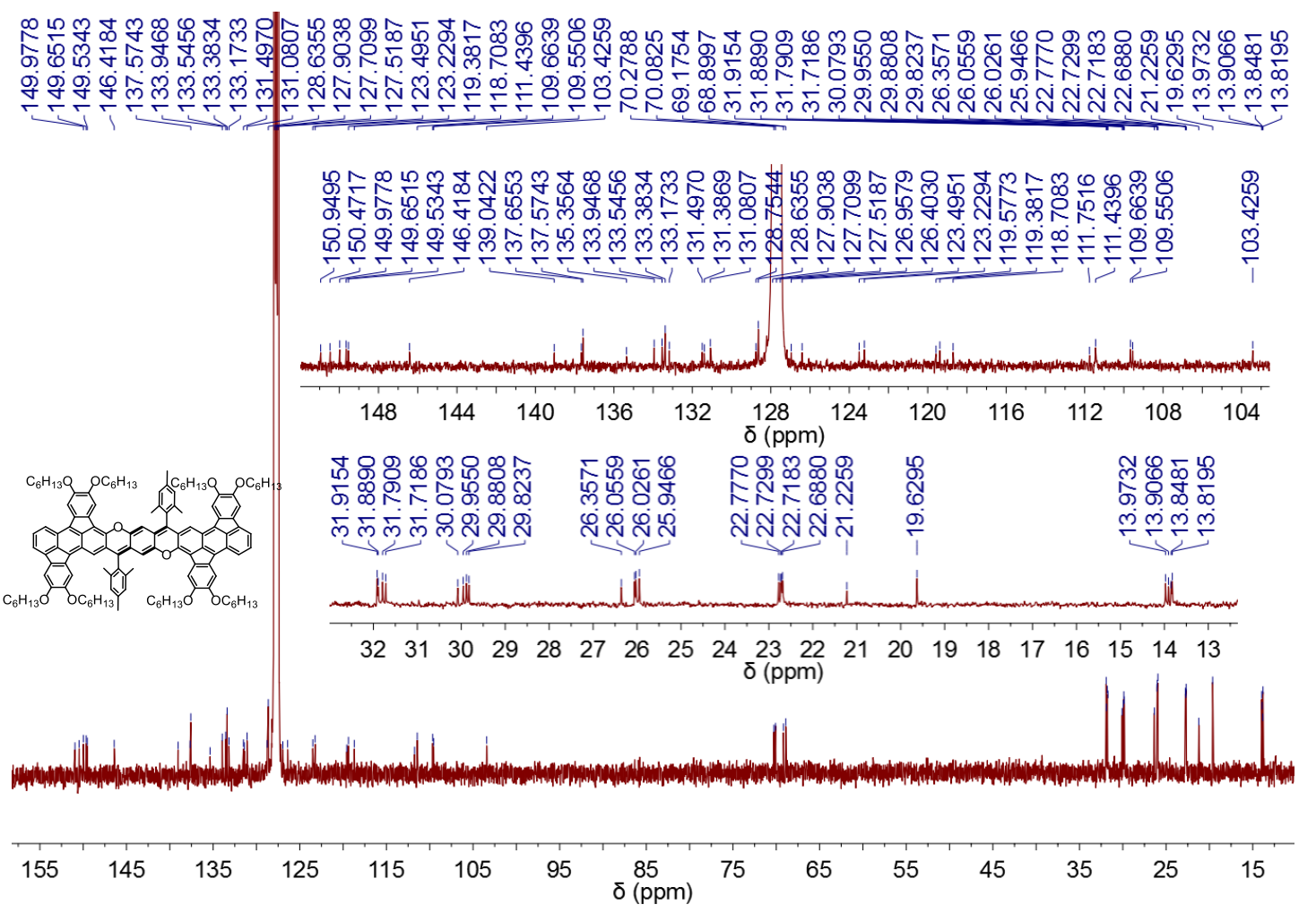

Figure S16. ${ }^{13} \mathrm{C}$ NMR spectrum of RBR (125 MHz, $\left.\mathrm{C}_{6} \mathrm{D}_{6}, 333 \mathrm{~K}\right)$.

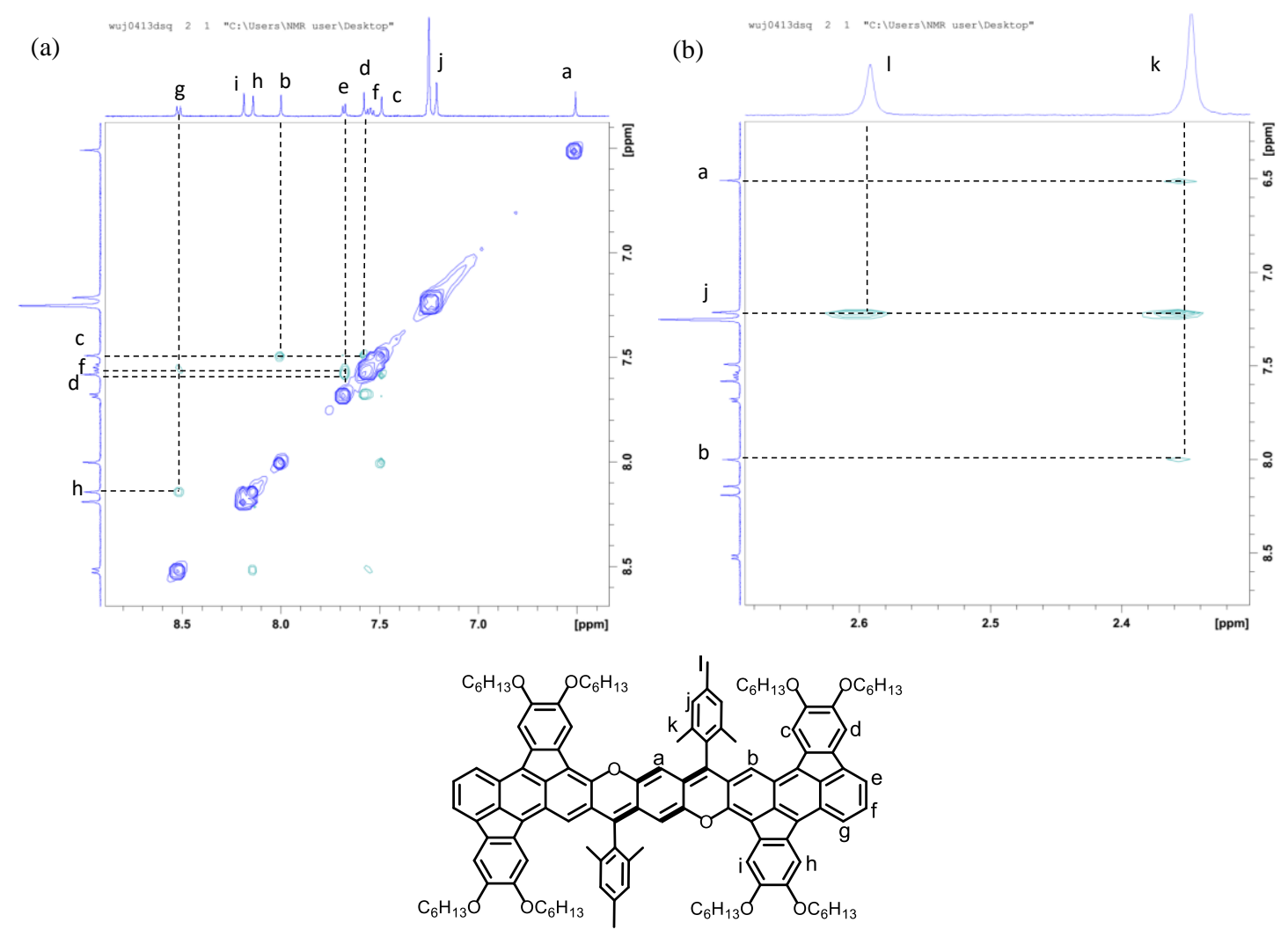

Figure S17. Partially zoomed spectra of 2D ROESY NMR spectrum of RBR with assignments (500MHz, $\left.\mathrm{C}_{6} \mathrm{D}_{6}, 333 \mathrm{~K}\right)$. 
(a)

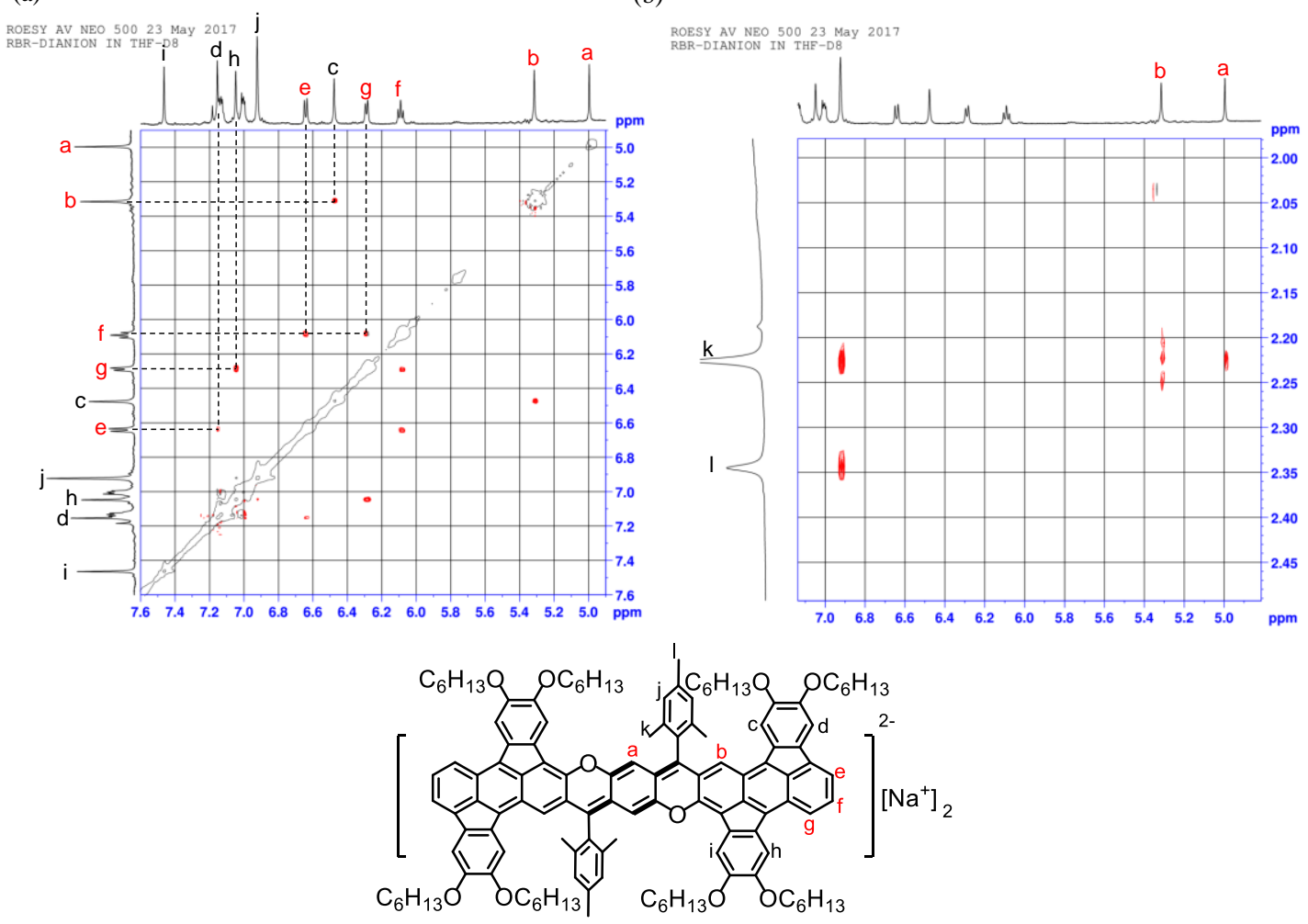

Figure S18. Partially zoomed spectra of 2D ROESY NMR spectrum of $\mathbf{R B R}^{\mathbf{2}-}$ with assignments $\left(500 \mathrm{MHz}, \mathrm{THF}-d_{8}\right)$.

\section{Appendix III: High resolution mass spectrum of RBR}

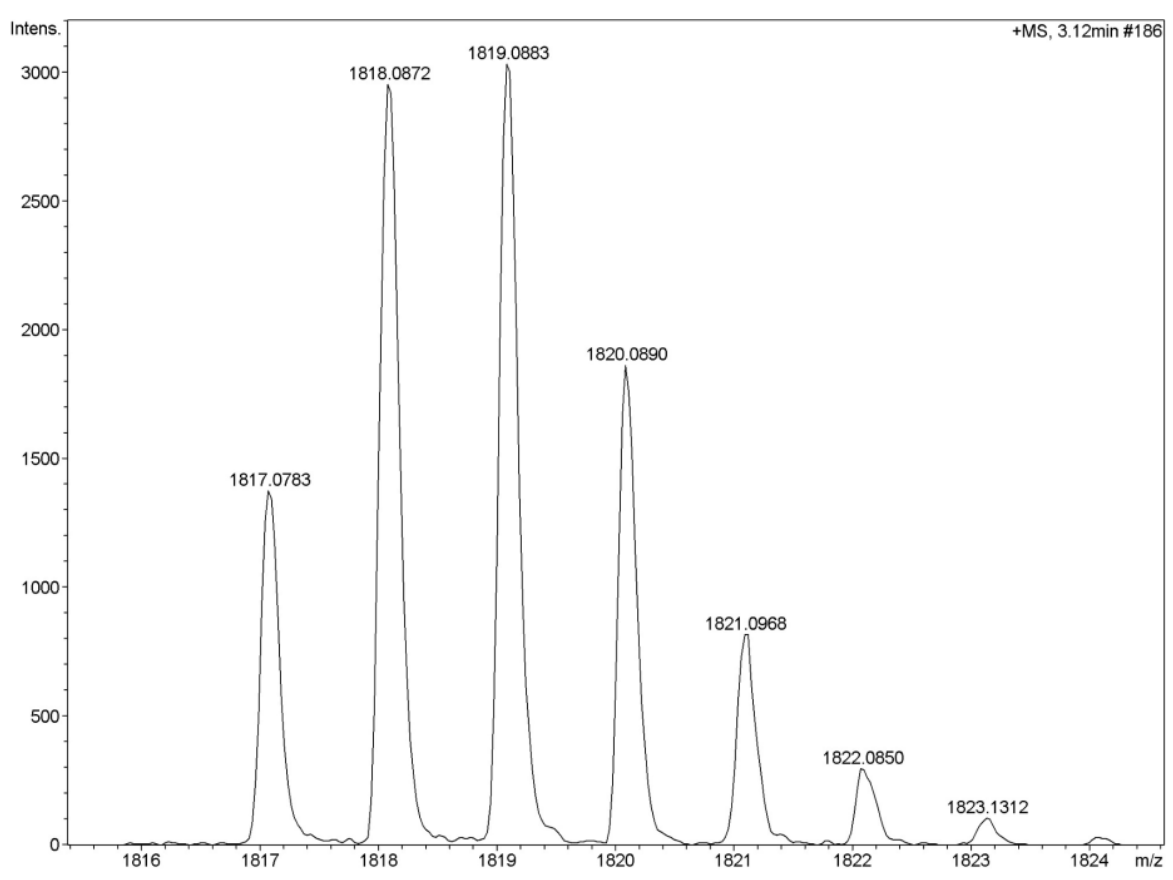

Figure S19. HR-MS (APCI) of RBR. 